\title{
Economic Convergence, Capital Accumulation, and Income Traps: Empirical Evidence
}

Cyn-Young Park \& Rogelio Mercado, Jr.

TEP Working Paper No. 1117

April 2017

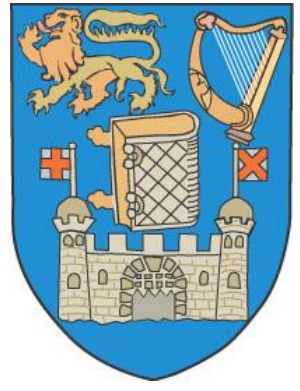

Trinity Economics Papers

Department of Economics

Trinity College Dublin 


\title{
Economic Convergence, Capital Accumulation, and Income Traps: Empirical Evidence
}

\author{
Cyn-Young Park* \\ and \\ Rogelio Mercado, Jr.**
}

April 2017

\begin{abstract}
This paper aims to examine the factors that increase the likelihood of economic transition to higher income status; that is, it tries to answer the question of why some economies move to a higher income country group while others do not. Using a quintile income distribution approach, we identify 62 economies that moved to a higher quintile income group from 1960 to the 2010 s out of a sample of 182 economies. Our findings show that higher physical and human capital growth and oil revenues are significantly associated with a greater probability of transitioning to higher quintile income group, although their effects vary not only across income groups within a sample period but also across different periods. Our results indicate that economies that have attained substantial capital accumulation (either physical or human, or combination thereof) and/or are blessed with oil resources have avoided income traps and demonstrated a successful and often steady transition to higher income groups.
\end{abstract}

Keywords: economic convergence, capital accumulation, middle-income trap JEL codes: O10, O11, $\mathrm{O} 40$

\footnotetext{
* Cyn-Young Park (cypark@adb.org) is Director of the Economic Research and Regional Cooperation Department at the Asian Development Bank. ${ }^{* *}$ Rogelio Mercado, Jr. (rogelio.mercado@northumbria.ac.uk) is a Lecturer in Economics (Assistant Professor) at Newcastle Business School, Northumbria University. The views expressed in this paper are those of the authors alone and do not reflect the official views of the ADB.
} 


\section{INTRODUCTION}

Economic convergence in per capita income has been studied by economists for several decades. The neoclassical growth model implies that countries with low per capita income would grow faster than countries with high per capita income, and over time will converge. However, empirical evidence on this "absolute convergence" has been elusive as considerable variations in per capita income between different countries remain. The consensus in development economics now points to "conditional convergence", where countries converge to their country-specific long-run income based on their structural characteristics. ${ }^{1}$

One would have thought that the debate on economic convergence in the 1980s and 1990s has been settled by now. But since Gill and Kharas (2007) introduced the term "middle-income trap" to describe selected East Asian economies that had not reached high-income level status by the 2000s despite their remarkable growth rates in the previous decades, a renewed policy debate on how to avoid or escape the middle-income trap has emerged. It is important to stress that both economic convergence and the middle-income trap are conceptually related as the factors which would allow economies either to surpass or to get stuck in middle-income trap depend on the economic convergence path they are following. Economies that escape the middle-income trap could exhibit absolute convergence, while those that get stuck could exhibit conditional convergence.

A growing literature has attempted to explain the phenomenon and find evidence of a middle-income trap. Eichengreen et al. (2011 and 2014) argue that once countries reach a certain level of income, they tend to experience a sudden growth slowdown. While they suggest that the inflection levels could be $\$ 10,000-\$ 11,000$ and $\$ 15,000-\$ 16,000$ (at 2005 US dollar purchasing power parity), they argue that "slowdowns are less likely in countries where the population has a relatively high level of secondary and tertiary education and where high-technology products account for a large share of exports." Aiyar et al. (2013) also define a middle-income trap as a sudden deceleration in growth. The authors argue that countries in the middle-income category, like some Asian and Latin American emerging market economies, are disproportionately more likely to experience growth slowdowns. They examine factors that cause a sudden drop in growth rates, such as the role of institutions, demographic structures, infrastructure, the macroeconomic environment, and output and trade structures. ${ }^{2}$ Implicit in these studies is the notion that most countries find it difficult to achieve convergence as their growth rates slow.

Felipe et al. (2012) study historical transitions across income groups to identify the economies caught in the middle-income trap, those that take longer than the median number of years to cross the highincome threshold. In a follow-up study, Felipe et al. (2017) refute the idea of a middle-income trap as a permanent state and argue that economies simply differ in their pace of transition from middle to high-income. Im and Rosenblatt (2015) examine historic transition phases in the cross-country distribution of income using both absolute and relative income thresholds. Their analysis of the transition matrix offers little support for the notion of a middle-income trap, as they find no systemic pattern for a middle-income economy to stay in the same income bracket. ${ }^{3}$ Han and Wei (2017) also reject the middle-income trap by using a transition matrix analysis, similar to Im and Rosenblatt (2015). They argue that relative growth depends on different country fundamentals and policy factors such as the size of the working-age population, financial development, and macroeconomic stability.

\footnotetext{
1 See Barro (1991), Barro and Sala-i-Marin (1992), Barro (1996), Cohen (1996), Romer (1990), Sachs and Warner (1995), Solow (1956), Solow and Samuelson (1953), and Swan (1956) for the literature on economic convergence and endogenous growth theory.

2 Eichengreen et al. (2014) and Bulman et al. (2014) consider sources of the middle-income trap from growth perspective, such as diminishing returns to capital and total factor productivity. In contrast, Gill and Kharas (2007 and 2015) and Aiyar et al. (2013) look into structural characteristics of economies-such as demographics, infrastructure, institutions, and economic structure-in relation to the sources of growth slowdowns.

3 Using individual country transitions to and from various income levels for a sample of economies, the authors find that, on average, middle-income countries have a $30 \%$ probability of moving to a higher income group.
} 
However, there are noticeable differences in what researchers directly or indirectly refer to as a middle-income trap. ${ }^{4}$ These differences pertain to both the definition of "trap" and what constitutes a "middle-income" country. ${ }^{5}$ More importantly, these studies differ in their approach and methods in identifying and analyzing cross-country variation; and on whether the middle-income trap is about growth slowdowns (Eichengreen et al. 2014; Bulman et al. 2014; Aiyar et al. 2013) or about the transition to high-income status (Felipe et al. 2012 and 2017; Im and Rosenblatt 2015; and Han and Wei 2017).

Empirical regularities also suggest that most economies grow positively and, therefore, eventually reach a certain high-income threshold. Even if a country's economic growth slows, as long as growth is sufficiently positive, the country will reach a high-income status given sufficient time. In this context, most middle-income traps are temporary and what matters only is the speed of convergence.

Earlier empirical studies present some issues. First, empirical evidence of a middle-income trap becomes rather meaningless if whether a country is stuck in a middle-income trap depends on how the study defines a middle-income trap and how the middle-income threshold is set. Second, the finding that most economies move to higher income status given time is also problematic from a policy point of view. From an analytical viewpoint, it may be important to distinguish patterns of economic convergence; whether all countries converge to a unique equilibrium or different groups of countries converge to different equilibriums. However, in practice, the former concept would not allow for public policy to play a role in steering a country transition to a higher income status. If multiple steady states in economic convergence exist, it would be important to understand what makes a country follow a higher convergence path. For example, Ito (2017) argues that there are three convergence paths in Asia: low-income, middle-income, and high-income. A shift from one path to a higher one requires implementing economic and political reforms that generate innovation. Without reform, economies may stay in a low-income steady state or a middle-income trap.

Agenor (2016) has also noted that such debate "does not invalidate the middle-income trap as a useful concept in understanding the experience of individual countries and the policy challenges that productivity slowdowns, and the transition to high-income status, present. Therefore, a pragmatic approach would be to assess how growth patterns may change across countries with different income levels and identify some of the key structural features that are consistent with various stages of economic development." Bulman et al. (2014) argue that the determinants of growth at the low-income level are different from those at the high-income level. Their model implies that a transition from low to high-income status can be smooth if a country redirects its resources to factors that are important for achieving high-income growth.

Economic growth is a dynamic process. Growth patterns vary not only across countries, but also likely evolve over time even in the same country. That is, drivers of economic catch up would evolve over time and across different income groups. First, different technologies and institutions generally now available but absent from earlier decades may make a difference; for example, IT (mobile technology) was not available in the 1960s and 1970s. Second, countries in higher income groups may need different economic factors and policies to move up; for instance, some Asian economies successfully pursued export-driven growth based on abundant low cost labor (Ozawa, 2005). However, with growing income Asia loses the competitiveness derived from low wages and needs innovation or more sophisticated human capital.

\footnotetext{
${ }^{4}$ Most studies suffer from the limitation of somewhat arbitrary assumptions in setting thresholds for middle-income economies in addition to a range of empirical problems such as: sample selection bias; data availability and consistency; and measurement and specification errors. See Gill and Kharas (2015) and Glawe and Wagner (2016) for an extensive literature review on the concepts, methodologies, and causes of the middle-income trap.

${ }^{5}$ Semantics aside, a "trap" refers to a position or situation from which it is difficult or impossible to escape (Merriam-Webster Online). Based on this definition, a "trap" is the "difficulty" or "impossibility" of middle-income economies from moving up to high-income status. A rejection of the idea certainly implies that it is not impossible for middle-income economies to reach high-income status. However, it disregards that fact that most middle-income countries are finding it difficult to do so.
} 
In this study, we tie together economic convergence, the middle-income trap, and sources of economic growth by considering which factors have allowed successful countries to move to the higher-income group. Specifically, this paper asks: 1) which countries have made successful transitions to a higher income country group; 2) what factors are significant in explaining cross-country variation in their likelihood of moving to the higher income group; and 3) do these factors evolve over time and across different income levels?

Addressing these questions will inform both researchers and policy makers on several important points. First, we propose a new methodology to identify which economies have moved to higher income groups in any given time period. Identifying successful candidates is the very first step in understanding what factors enabled them to raise incomes. Second, knowing which factors are significantly related to a greater likelihood of moving to higher income group will help in designing and implementing economic policies that support the catch-up process and/or in avoiding growth slowdowns. ${ }^{6}$ Lastly, these questions highlight the need to understand cross-country variations in growth dynamics, not only in the context of varying stages of economic development, but also over time. For instance, factors that are significant in increasing the likelihood of moving up to a higher income group change across different periods of time. This adds another dimension to growth dynamics.

To address these questions, we proceed as follows. In Section II, we adopt a new methodology to identify the "movers": i.e., the economies that transitioned to a higher income group in any given period. Instead of using an absolute or a relative income threshold in identifying country income groups, we use a quantile income distribution approach, where we group countries in order of their income quintiles. This reduces the arbitrariness of identifying income groups based on per capita income levels or ratios relative to a reference country. In Section III, we present our empirical specification using a cross-sectional probit regression to help identify which factors are significant in explaining cross-country variation on the probability of moving to higher quintile income groups. We test factors based on theory and empirical evidence. Section IV presents our baseline probit estimates regardless of a country's quintile income group at a given decade from the 1960 s to the 2010 s. Then, we present decade by decade conditional probit estimates before providing sensitivity tests. Lastly, Section V provides concluding remarks and policy implications.

Our study differs from previous literature in several aspects. First, instead of using either absolute or relative cut-off thresholds in identifying middle-income countries, we use distributional approach based on income quintiles. ${ }^{7}$ Using this approach, we identify the per capita income level of all economies and then group them by their income quintiles. This eliminates the arbitrariness of setting thresholds in absolute and relative income levels. Second, our paper specifically looks at which factors are relevant for those countries that have successfully transitioned to higher income levels. This differs from Eichengreen et al. (2014) and Aiyar et al. (2013), who approached middle-income trap in the context of economic slowdown. Our study focuses more on which factors increase a country's likelihood of success in escaping income-level growth restrictions such as the low- or middle-income traps. Lastly, unlike Felipe et al. (2012 and 2017), Im and Rosenblatt (2015) and Han and Wei (2017), who implicitly assumes a universal growth pattern based on the concept of the middle-income trap, our paper recognizes growth as a dynamic process whose patterns will differ across countries and evolve over time even in the same country.

Using an income quintile distribution approach, we identified 62 economies that have moved to a higher income quintile or have demonstrated economic catch-up in a given decade. The identified economies are a highly heterogeneous group, i.e. they differ substantially in economic size, natural resource endowment, geographic region, and economic and political structures. Considering various

\footnotetext{
${ }^{6}$ In this regard, we are referring to absolute convergence such that middle-income countries would aspire to achieve highincome status.

7 See Glawe and Wagner (2016) for a review of previous studies which used either absolute or relative approach in identifying middle-income countries.
} 
sources of growth and economic characteristics, our results show that physical and human capital growth and oil revenues are significantly associated with a greater likelihood of moving to higher income quintile groups. However, our results show that not only do the relevant factors vary in their significance across income groups within a sample period, but they also vary across different periods. These findings are robust to sensitivity tests.

\section{ECONOMIC CATCH-UP AND STYLIZED FACTS}

This section addresses the first question laid out in this paper. It identifies which economies have exhibited convergence based on a quantile income distribution approach. This section first discusses the absolute and relative approach in defining country income groups. It then examines another approach in which stylized facts are presented.

\section{A. Absolute and Relative Income Approaches in Identifying Income Groups}

Previous studies on the middle-income trap often relied on absolute or relative income thresholds in identifying the income progress. First, several studies have used "absolute" income thresholds or cutoff points based on average per capita income (usually expressed in constant prices, US dollar, and at purchasing power parity). These thresholds are often consistent with the World Bank classifications on low-income, low middle-income, high middle-income and high-income countries. For instance, Eichengreen et al. (2011 and 2014) identified the middle-income range as greater than $\$ 10,000$ (at 2005 constant international prices) using Penn World Tables 6.3 and 7.1 for 1957-2010. In contrast, Felipe et al. (2012) used $\$ 2,000$ to $\$ 11,750$ (in constant 1990 US dollar prices at purchasing power parity) using the Maddison and International Monetary Fund dataset for 1950-2010.

Second, other studies evaluate the income of countries relative to a reference country, such as the United States, or a group of countries. The idea behind this "relative" approach is to assess economic catch-up or convergence. For instance, a relative share of 0.60 would mean that the country's income level is about $60 \%$ of the reference economy. If the share goes up, to say $70 \%$, then that country has exhibited convergence as its income share relative to reference income level has increased. This approach has been taken by Agenor and Canuto (2012), Bulman et al. (2014) and Im and Rosenblatt (2015), among others. An advantage of the approach is that middle-income countries would be defined by relative share to a reference country or group, which in itself is a moving target: i.e., the reference economy's per capita income is also increasing over time. Im and Rosenblatt (2015) divide middle-income countries into three groups, those with $15-30 \% ; 30-45 \%$ and $45-60 \%$ of income relative to the United States. However, if the reference country or group is fixed, this approach may not necessarily capture the true middle income. That is, there is no guarantee that the reference country will continue to be the reference country over a long time horizon; the US economy may give a way to the Chinese economy for the top income country in 100 years.

Figure 1 presents the decade average per capita income (in constant US dollars at purchasing power parity from Penn World Table 8.0) for a sample of countries over six decades. ${ }^{8}$ The figure illustrates several points. First, the cross-country variation in per capita income growth patterns is considerable. Some economies have attained a significant increase in income level, while others have not. For instance, Taipei,China and Rep. of Korea (Korea) have achieved rapid and consistent increases in per capita income from their low bases in the 1960s. In fact, Korea has reached the same average per capita income as Spain in 2010s, although it started from a much lower average per capita income than Spain in the 1960s. In contrast, the Philippines has made a very slow income progression. Second, the choice of income thresholds will lead to arbitrary classification of economies into different income groups. For example, if we take economies with less than $\$ 5,000$ average real per capita income in the 1960s as middle-income countries and set $\$ 10,000$ as the cut-off level in defining middle-income countries in 2000s, then Brazil, the Philippines, and Thailand would still be in the

\footnotetext{
${ }^{8}$ Data for the 2010 s refers to the per capita income average from 2010 to 2014, based on Penn World Table 8.0.
} 
middle-income group while Argentina, Malaysia, Korea, and Taipei,China would have made the higher income groups. However, if we set the cut-off to $\$ 15,000$ in 2000 s, then Argentina would be still considered a middle-income country.

Instead, Figure 2 shows the relative per capita income of selected economies on the median per capita income of the top $20 \%$ income group. The data are based on the decade average values of per capita income using Penn World Table 8.0 data at constant US dollar purchasing power parity. The figure plots relative income in the 1960s versus the 2010s. Countries along and below the 45degree line are those which do not exhibit convergence relative to the top $20 \%$ income group. It is noticeable that a substantial number of countries have experienced stagnation in per capita income relative to the top $20 \%$ income groups. If we take $15-60 \%$ income share as the cut-off income to define middle-income countries, in line with Im and Rosenblatt (2015), then a significant number of countries would have been stuck at middle-income group for about five decades. ${ }^{9}$ They would include Argentina, Chile, South Africa, and Mexico, among others.

\section{B. The Quantile Income Distribution Approach and Stylized Facts}

Using absolute or relative income thresholds leaves the income classification subject to arbitrary choice of these thresholds. Therefore, we propose a quantile income distribution approach. Statistically, quantiles divide a sample range into equal parts with equal probabilities. In this paper, we specifically divide our country sample into quintiles, five equal groups. ${ }^{10}$

The main advantage of this approach is that the sample size will determine the cut-off levels in defining income groups. This relieves us the need to justify where we set the thresholds. Another advantage is that specific income thresholds no longer matter. Income classification is now determined by the rank of individual economies in income distribution. When comparing the order of countries between income levels and relative shares, we find no difference between the two as the relative shares are simply scaled by a common value, which is the relative income value of the reference country of the group of countries.

Potential issues still exist about this approach. First, the cut-off values will depend on the sample size. Ideally, the larger the sample size the more stable the cut-off points. We address this problem by using the Penn World Table 8.0, which includes data for over 182 countries from 1950-2014. Unfortunately, the dataset does not include several Pacific economies, which would have made our sample reach 200 or more countries. Second, the choice of whether to use quartiles or quintiles would somehow matter if we try to identify the movers. We choose to use quintiles as a baseline on the premise that countries within each quintile group would be more homogeneous than in a larger quartile group, and hence allow more reasonable comparison of their initial conditions when we try to identify the factors that influence the transition to higher income groups.

From the Penn World Table 8.0 data, we use values on real per capita income (expressed in constant US dollars at purchasing power parity) starting in 1960 and take the decadal average to construct the income quintile distribution for 182 countries over six sample periods. ${ }^{11}$ Table 1 presents the per capita income quintile classification of our sample. The highest income group is assigned the number (5) as it pertains to the highest quintile income group, and the lowest is assigned the number (1).

Based on Table 1, we can identify the economies that moved up to a higher quintile income group between 1960 to 2014. Several observations can be made. First, some countries stayed in the same quintile income group for over five decades, regardless of whether it was the highest or lowest income quintile grouping. For example, Malawi stayed in the first quintile group throughout the sample period,

\footnotetext{
${ }^{9}$ These countries lie around $0.15-0.5$ in the $x$ - and $y$-axes of the lower panel of Figure 2. They would include those economies below the 45-degree line.

10 We ran sensitivity test using quartiles in Section IV, and our baseline results using quintiles hold.

11 We use 1960 as our start date because out of the sample of 182 countries, less than 90 have any data for the 1950s. We have a 111 countries with data available from the 1960s, which increases the number of usable observations.
} 
while Ecuador remained in the third quintile group. Second, countries can move up and down across income quintiles. The cases in point are Iran and Iraq. This again highlights an advantage of using the income rank rather than specific income levels, whether absolute or relative. Classification by income rank makes the identification of movers less sensitive to arbitrary decisions about the income level or the reference country. Third, some countries move up or jump only once, while others make steady progress over time. For instance, Korea moved up several times throughout the sample period, while Thailand moved up to third quintile group in the 1980s then stayed there. In contrast, Equatorial Guinea jumped from the first quintile to fourth quintile by the 2000s primarily due to its large oil revenues starting in the 1990s. Lastly, some countries moved down one or several times. Senegal moved down to second quintile group from third quintile group in the 1970s and then moved down to the lowest income group in the 2000s. These observations clearly reflect the growth dynamics of countries and that the convergence or divergence experience of countries are truly varied.

Table 2 presents the summary statistics of quintile groups, including the reference income levels, for in 2010s using the quintile income distribution approach. The first quintile group has a maximum annual income of $\$ 3,231$ and a median income of $\$ 1,568$. The second quintile group has an income range of $\$ 3,445$ to $\$ 9,400$ with median of $\$ 6,050$. The table presents the same summary statistics for the third, fourth, and fifth quintile income groups. Among five different quintile groups, the third quintile group - with an income range of $\$ 9,550$ to $\$ 17,652$ and a median income of $\$ 12,699$ _roughly corresponds to the middle-income levels identified by previous studies in that its cut-off income levels are similar to those identified as the middle-income thresholds suggested by Eichengreen et al. (2014). Also noteworthy is that the first and fifth income groups have the highest variation in per capita income levels, whereas the third and fourth income groups have the lowest. These suggest that income variation is greater at the extreme end of the sample distribution, and smaller at the middle.

Table 3 presents a list of the economies that demonstrated economic catch-up or convergence by moving up in the income quintiles. The table columns indicate which decade the countries moved up, while the rows indicate which quintile income group they move into. For instance, Korea moved up to the third quintile group in the 1970s from the second quintile group in the 1960s. It then moved to the fourth quintile group in the 1980s and stayed there until moving to the highest income group in the 2010s. In total, we identified 62 economies which moved to a higher income quintile during the sample period. However, we note that countries do not necessarily transition to only higher quintiles. For example, Spain has moved to the highest income group in the 1970s, and then moved to the original income group in 2000s. This suggests that at some point between 1970s to 2000s, it has moved down to a lower quintile income group. Table 1 confirms that this is indeed the case for Spain as it moves down from the fifth income group in the 1970s to the fourth income group in the 1980s and 1990s.

Table 3 also shows that economies that have moved to a higher income group are varied in size and structure. The group includes small economies like Aruba, Bahamas, Malta, Turks and Caicos, among others. ${ }^{12}$ Oil exporters such as Bahrain, Equatorial Guinea, Oman, Saudi Arabia, Iran, and Iraq are also present, suggesting that natural resources play an important role in per capita income increases. The identified economies also vary with regard to region, government structure, demographic characteristics, and others. In summary, this group is highly heterogeneous. ${ }^{13}$ This further motivates research identifying which factors allowed these economies to transition to higher quintile income group.

\footnotetext{
12 We include small economies as the classification and cut-off levels of income groups depend on the sample size. Unfortunately, Penn World Tables 8.0 does not report values for Pacific economies. Ideally, they should be included.

${ }^{13}$ To see whether our list of movers exhibited economic catch up, we regressed catch-up rate on initial per capita income level and lag per capita income growth. Our catch-up rate is computed as $C U=100 \times \frac{\Delta\left(y_{i, t}-y_{t}^{*}\right)}{\left(y_{i, t-1}-y_{t-1}^{*}\right)}$, where $\mathrm{y}^{*}$ refers to the median per capita income of the top quintile income group (European Commission 2004). If the initial level of per capita income and lag per capita income growth are significantly negative, then economies would exhibit catching-up relative to the median income of top quintile income group. The results show that almost half of our 62 movers have significantly reduced their income differential with respect to the median income level of the top income quintile. Results are available from the authors by request.
} 


\section{EMPIRICAL SPECIFICATIONS AND DATA SOURCES}

We identified in the previous section the economies that moved up to a higher quintile income group. These "movers" do not appear to share any clear characteristics. In order to address the second question of the determinants of the likelihood of moving to a higher quintile income group, and third question on the significance of these determinants over time, we use a cross-section probit specification:

$$
P\left(m_{i}=1\right)=\beta^{\prime} x_{i}+\varepsilon_{i}
$$

where $m_{i}$ is a dummy variable with takes the value of 1 if the economy has moved to a higher quintile income group; and 0 otherwise. $\beta$ ' is a column vector of coefficients. $x_{i}$ is a row vector of determinants, and $\varepsilon_{i}$ is the cross-section error term. Given that there are only a few movers in each decade, we use complementary logarithmic (cloglog) framework, which assumes a cumulative distribution function to account for the fact that less than $10 \%$ of our dependent variable has a value of 1 .

We first estimate Equation 1 for each decade regardless of which quintile income group countries fall into and regardless of which decade it transitioned to a higher quintile income group. The idea behind this specification is to determine which factors explain the cross-country variation in the likelihood of transitioning to a higher quintile income group for all identified movers. The row vector of determinants pertains to the within decade growth or average values, while the dependent variable refers to the dummy variable, which takes the value of 1 if the country has moved to a higher quintile income group within the total sample period.

Next, since movers transitioned to higher income group in different decades, we run Equation 1 for each decade where the dependent variable takes a value of 1 if a country has moved to a higher quintile income group in the following decade. This specification now considers which factors enabled a country to move to a higher quintile income group in a decade regardless of which income group it belongs to in the current decade. ${ }^{14}$ This addresses potential endogeneity issues arising from reverse causality of variables.

Lastly, we estimate Equation 1 for each decade conditional on being in a given quintile income group. This allows us to determine the relevant factors for a specific income group in their chances of moving up. The estimates would then trace the relevance of determinants across the decades and across income groupings. Again, the row vector of determinants pertains to the within decade growth or average values, while the dependent variable refers to the dummy variable, which takes the value of 1 if the country has moved to a higher quintile income group in the following decade.

Our independent variables include the following. First, we take the log value of the initial per capita income level at the start of each decade. This acts as a control in our first and second estimation as we do not impose conditionality as to which quintile income group a country is coming from. Second, we include within decade population growth, physical capital growth, productivity growth, and human capital growth. ${ }^{15}$ Neoclassical and endogenous growth theory predicts that higher population growth will reduce the economic growth rate, while physical capital growth, productivity growth, and human capital growth will increase it. ${ }^{16}$ These factors account for the sources of economic growth given by

\footnotetext{
14 The second regression results pertain to causality, while the first regression results are correlations over decades.

15 Ideally, we should be using the labor force growth rate. However, given data unavailability, we are restricted in using overall population growth. The two measures should be highly correlated based on the assumption that the population growth rate moves in the same direction as the employment growth rate.

${ }^{16}$ Physical capital growth could lead to lower economic growth due to diminishing returns to capital. However, the inclusion of productivity growth and human capital growth could lead to increasing returns to capital, as pointed out by Romer (1990), Barro (1991), Barro and Sala-i-Marin (1992), Barro (1996), Howitt and Aghion (1998), Mankiw et al. (1992), and Stokey (2015).
} 
the production function. Data on initial per capita income, and growth in populations, physical capital, productivity, and human capital are taken from the Penn World Table 8.0.

Third, we include a measure of civil liberties, taken from the Freedom House Country Ratings and Status index from 1973 to 2016 . We denote a value of 7 for the highest degree of freedom and 1 for the lowest degree of freedom. Values pertain to average value within the decade. Since our sample period begins in 1960s and data from Freedom House is available from 1973 onwards, we use 1973 data for the 1960s. We chose to use the Civil Liberty Index, instead of Political Rights Index, as it includes "rule of law" which is indicative of the degree of contract enforcement. Previous studies (including Aiyar et al. 2013; and Han and Wei 2017) have noted that quality institutions, governance, and rule of law provide a sound environment for investments and hence foster economic growth.

Fourth, we include decade average values of the saving-investment gap, which is basically the current account balance in percent of nominal GDP. This accounts for economies who are either external borrowers or lenders. We expect high saving-investment gap (a positive current account balance) to be associated with either higher or lower per capita income. The expected sign will depend on whether current account deficits translate to productive investments which lead to higher growth; or increase foreign liabilities which could trigger financial crisis and hence lower growth (Ghosh and Ramakrishnan 2012). Data are sources from World Bank's World Development Indicators and External Wealth of Nations (Lane and Milesi-Ferretti 2011).

Fifth, some countries we identified as movers in Table 3 are oil exporters. We include the decade average values of oil rent in percent of GDP from the World Bank's World Development Indicators to test for the impact of oil revenues. For countries with unavailable data, we treat them as zeros if no oil production or extraction is taking place. Resource rich countries might show higher likelihoods of moving to a higher quintile income groups by benefiting from the windfall gains of high oil prices at times (for example, as for the oil-exporting countries shown in Table 3). ${ }^{17}$

Lastly, we include a measure of inflation volatility, which is the within decade standard deviation of inflation. The data refers to the GDP deflator taken from the Penn World Table 8.0. Inflation volatility can be a proxy for mismanaged macroeconomic environment and policy, following Aiyar et al. (2013) and Han and Wei (2017). We expect that countries with higher inflation volatility would have lower likelihood of moving to higher quintile income group.

\section{RESULTS}

\section{A. Baseline Results and Sensitivity Tests}

Table 4 presents our baseline results, showing which factors are significantly correlated with crosscountry variation in the likelihood of moving to a higher quintile income group across different decades. We present two results, where we include productivity and human capital growth in one specification but not in the other. ${ }^{18}$ The results show countries that moved to a higher quintile income group tend to have higher physical capital growth throughout the total sample period. In addition, "movers" tend to have higher human capital growth in the 1970s up to 1990s; current account surplus in 1990s to 2000s; higher oil revenues in 1970s and 1980s, which corresponds to oil price spikes in those decades; but higher macroeconomic volatility in the 1960s and 1970s. In contrast, they tend to show lower population growth in 1970s and 2000s. Overall, the results show that successful movers

\footnotetext{
${ }^{17}$ A good example would be Equatorial Guinea, which has seen a dramatic increase in per capita income due to oil discovery and extraction from the 1990s on. This has allowed the economy to jump from first quintile income group to fourth quintile income growth as shown in Table 1.

18 We split the results into two, not only because of data availability for productivity and human capital growth, but also to differentiate between the standard neoclassical growth model from augmented-neoclassical and endogenous growth models.
} 
have consistently higher physical capital growth throughout the total sample period, and higher human capital growth in 1970s to 1990s than non-movers.

Table 5 presents the estimates on which factors significantly explain cross-country variation in the probability of moving to higher quintile income group in the next decade.

First, we find that higher physical capital growth is significantly associated with a greater likelihood of moving up the quintile income groups in the following decade. This is true with or without the inclusion of productivity growth and human capital growth. In fact, among the variables, capital accumulation appears to be the only significant determinant which explains cross-country variation across all sample periods. The estimates show that an increase in physical capital growth by $1 \%$ is significantly associated with greater probability of moving to a higher quintile income group by $1.3 \%$ in the 1960 s and $0.5 \%$ in 2000 s. $^{19}$

Second, the significance of determinants varies across decades. For instance, population growth is significant only in the 2000s, i.e. higher population growth reduces the likelihood of moving to higher income group in the following decade. Higher human capital growth significantly increases the probability of moving to a higher quintile income group in the next period, but only in the 1970s. Civil liberty is significant in the 1960s and 2000s. But the estimates capture that countries with high civil liberty such as the US, UK, and Germany tend to have a lower likelihood of moving to a higher income group. As these countries already have high income status in fifth quintile, their likelihood of moving up is significantly lower or even zero. The saving-investment gap is significant both in 1970s and 1990s. However, its effects differ in these periods. It is significantly positive in the 1970s, reflecting higher surpluses due to the commodity price booms in that decade, but significantly negative in the 1990s, reflecting persistent foreign borrowing in some developing and emerging economies, which led to several crises. Oil revenues have positive and significant impacts in the 1960s, 1990s, and 2000 s, while inflation volatility is marginally significant only in the 1990s. In summary, while population and human capital growth, oil revenues, and inflation volatility show the expected impact, their relevance varies across different decades. In contrast, civil liberties and saving-investment gaps show contradicting or opposing impact across different periods.

Taken together, the results in Table 5 point to varying impacts of the economic factors on income transition in different times. This implies that, except for physical capital accumulation, different times require different factors for an economy's transition to higher income group. This reinforces the concept of dynamic growth, which requires different policies and factors for economic growth and development at any given time in an evolving environment with technology advances, changes in social norms, and the progress of legal and institutional standards.

Table 6 presents the results when we run probit regressions by decade conditional on being in a given quintile income group. The estimates try to answer, for any economy in a specific income quintile, which factors are significantly associated with cross-country variation in the likelihood of moving to higher income group in the next decade. Since we are splitting the sample into quintile groups, each group sample size is very small. Consequently, we only test the significance of population growth, physical capital accumulation, and oil rent share to GDP. ${ }^{20}$ Several findings are noteworthy.

First, growth drivers vary in significance across quintile groups at a given period. For instance, higher capital accumulation is significantly associated with the likelihood of moving to second, third, and fourth quintile income groups but not for moving to the highest income quintile group in the 1970s, as shown in Table $7 \mathrm{~b}$. In contrast, higher population growth is significantly associated with lower likelihood of moving only to the third quintile income group, but not for other income groups in the 1970s. This implies that movers from second to third quintile group in 1980s have significantly lower

19 The coefficients are interpreted as follows: supposing that physical capital grew by $1 \%$ within a decade, this will increase the likelihood of moving to a higher quintile income group in the next decade by $0.5 \%$ in $2000 \mathrm{~s}$, all else held constant.

20 We include oil rent to account for oil exporters in our sample of movers. 
population growth, compared to non-movers, whereas this is not the case for other income groups. Similarly, higher oil income is significantly correlated with a greater likelihood of moving only to the second quintile income group, and not for other income groups in the same decade.

Second, not only do the determinants vary across quintile income groups at a given period, they also differ across decades. For instance, capital accumulation is significantly related to higher probability of moving to the second and fifth quintile income groups in 2000s as shown in Table 7e, as opposed to moving to the second, third, and fourth quintile income groups in the 1970s, as shown in Table 7b. Likewise, higher population growth is significantly correlated with a reduced likelihood of moving to the fourth and fifth quintile income group in 2000s, as in Table 7e, in contrast to moving to third quintile income group in 1970s.

In summary, Table 6 suggests that at any given time, the countries' development stages matter for growth drivers; that is, countries with different income levels would require different economic factors to sustain growth; and these factors also change over time.

Next, we consider the effects of interaction terms between population growth, and physical and human capital growth, instead of treating them separately. Table 7 shows the results on whether growth in the augmented capital-labor ratio, which accounts for increasing returns to scale in the endogenous growth model, is relevant in explaining cross-country variation in the probability of moving to higher quintile income group across all sample periods.

Our findings show that movers tend to have higher augmented capital-labor ratio growth such that the combined impact of physical and human capital growth (while accounting for population growth) is significant and positive for 1970 s onwards in specifications (2) to (5).

We also find that the growth in augmented capital-labor ratio is positive and significant in the 1960s and 1970s, such that higher growth is associated with an increased likelihood of moving to higher quintile income group in the following decade. While the findings are consistent with the baseline results, the interaction term is significant only in the 1960s and 1970s. We offer two possible explanations for this. First, financial crises in the 1980s and 1990s eroded capital stocks and negatively affected physical capital accumulation while relatively slow population growth maintains the capital-labor ratio regardless of slow capital increases in 2000 s. Second, the augmented capitallabor ratio does not capture the quality of human capital. ${ }^{21}$

Our empirical findings are quite robust to various sensitivity tests. First, we apply quartile income distribution, where we divided the sample into four instead of five equal groups. As a result, some of the countries identified in Table 3 are no longer included, while some countries will now be included based on the new cut-off income level. For instance, Iran drops from the sample of movers, while Malta and Czech Republic are now included.

Table 9 presents the probit regression results from the quartile income grouping. Notice that capital accumulation remains significant across all sample periods and human capital growth now appears significant both in 1960s and 1970s. In addition, oil income also remains significant for 1990s and 2000 s with the expected sign. Overall, the main results remain intact; both quartile and quintile income group results suggest that capital accumulation, human capital, and oil income significantly increase the likelihood of moving to higher income group.

Second, we dropped the economies that moved both up and down over the sample period and instead focus on those which have moved only upwards and remained in a higher quintile income group in

${ }^{21}$ We considered using mathematics and science average test scores from the National Center for Education Statistics (NCES) Trends in International Mathematics and Science Study (TIMSS) in the 1990s and 2000s for selected economies in Table 11. Our results show movers tend to have higher quality of human capital than non-movers in specifications (1) and (2). We flag caution in interpreting specifications (3) and (4) as they rest on a smaller sample size. 
the next decades. Table 10 presents the results excluding those countries which transitioned to lower quintile income group after moving to higher group. Our baseline results hold. Higher physical and human capital growth, and oil income are significantly associated with higher likelihood of moving to higher income group.

\section{B. Analysis of Results}

Our empirical results show that physical capital growth significantly explains cross-country variation in the likelihood of moving to a higher quintile income group. That is, capital accumulation appears to be a crucial factor in pushing an economy up to a higher income level, whether it is from a low- or a middle-income group. This finding is consistent with the mainstream growth theories but at odds with some of the identified sources of the middle-income trap (Agenor 2016). A crucial assumption under the neoclassical growth theory is that physical capital exhibits diminishing marginal returns, such that capital accumulation could not sustain long-term growth. However, endogenous growth theory, which spurs from empirical evidence from the 1980s, points to increasing marginal returns to capital augmented by human capital. Furthermore, technology advances will allow increasing marginal returns to capital (as in the case for endogenous growth model). Our results on interactive terms (Table 7) are also consistent with such endogenous growth model predictions.

Our results also point to the importance of human capital growth in the convergence process. Table 4 shows that countries with higher human capital growth tend to have greater likelihood of moving to higher quintile income groups from the 1970s to 1990s at any initial quintile group. We also find that higher human capital growth increases the probability of moving to a higher quintile group, as was shown in Table 5, but only for the 1970s. Nonetheless, the significant positive impact of human capital growth across different decades holds when we use quartile income distribution and exclude economies that moved up and then down in our list of movers. Overall, the findings support the importance of human capital growth in explaining cross-country differences in the catching-up process.

The findings also highlight the positive impact of oil income for countries which derive significant shares of income from oil revenues. The results are robust specifically in the 1990s and 2000s, perhaps due to growing demand for oil in emerging and developing countries in these decades, which increases revenues for oil exporters. Setting aside the adverse impacts from overreliance on natural resources (such as Dutch disease), we include oil exporters in our sample to account for all country factors which allowed them to move to a higher income group.

Table 6 showed the time-varying nature of growth drivers. Growth drivers vary not only across different income groups within a sample decade but also across different decades. In Table 6, capital accumulation is shown to be significant for moving up among most income groups in the 1960s, 1970s, and 2000s but less so in 1980s and 1990s, reflecting the effects of economic crises in developing and emerging economies in those decades. In fact, higher capital accumulation in these decades coincided with the upward movement of several East Asian economies from third or fourth quintile income groups to either fourth or fifth quintile income groups in the succeeding decades.

Lastly, we find evidence that civil liberty, the saving-investment gap, and inflation volatility matter in explaining cross-country variation in the probability of moving to higher quintile income group. In fact, in some cases, their relevance appears robust. However, their relevance varies depending on the decade and model specification, consistent with the observation of time-varying growth patterns. Among the variables we have tested, productivity growth does not appear significant across specifications and sensitivity tests. While there may be misspecification or measurement issues of productivity growth, it is also possible that physical and human capital growth might have already captured the major growth effect of increased productivity as capital accumulation and innovation are complementary determinants of long-run growth (Howitt and Aghion, 1998, and Stokey, 2015). 


\section{SUMMARY AND POLICY IMPLICATIONS}

In this paper, we aim to identify the factors that positively influence the likelihood of moving up the income ladder. Unlike previous studies, we adopted a quantile income distribution approach, where we divided our sample of 182 economies into five income groups. Using this approach, we identified 62 economies that moved to a higher quintile income group from 1960 to the 2010s. These movers are highly heterogeneous. They differ in economic size, region, structure, sources of growth, and country characteristics.

Employing a cross-sectional probit regression with a complementary distribution function, our findings show that higher physical and human capital growth (or a combination thereof) and oil revenues are significantly associated with a greater probability of transitioning to a higher quintile income group, although their significance not only varies across income groups within a sample period but also across different periods. Our results are robust to several sensitivity tests.

Our findings have clear policy implications. First, transitioning to a higher income group requires continuous physical and human capital investment. Not only that the quality of human capital should increase through education and training, but more so that physical capital should grow and be productive. ${ }^{22}$ As shown in our results, countries that have made a successful transition to higher per capita income have high growth rates of physical capital. Unfortunately, the debt crises in the 1980s and emerging markets crises in 1990s have left a lasting impact on capital accumulation, i.e. investment growth has significantly declined for more than a decade. Consequently, investment slowdown limits capital accumulation and the chances of income transition. Second, our findings show that resource endowments, particularly oil, enable economies to move up the income ladder during oil price booms. However, these economies need to learn how to efficiently manage resource revenues to build physical and human capital to sustain their longer-term growth. Several oil-exporting countries have now set up sovereign wealth funds and invested in productive sectors. Lastly, a sound macroeconomic environment, high quality institutions, and financial and trade openness still matter in economic growth and development process. For instance, attracting foreign direct investment may help capital accumulation, while past literature offers clear evidence that these factors help attract foreign direct investment.

22 Physical capital stock in Penn World Table 8.0 refers to the cumulative investments in buildings and machineries. 


\section{REFERENCES}

Aiyar, S., R. Duval, D. Puy, Y. Wu, and L. Zhang. 2013. Growth Slowdowns and the Middle-Income Trap. IMF Working Paper No. 13/71. Washington, DC: International Monetary Fund.

Agenor, P.-R. 2016. Caught in the Middle? The Economics of Middle-Income Traps. Journal of Economic Surveys, (Forthcoming).

Agenor, P.-R., and O. Canuto. 2012. Middle-Income Growth Traps. Policy Research Working Paper No. 6210. Washington, DC: World Bank.

Barro, R. 1991. Economic Growth in a Cross-Section of Countries. Quarterly Journal of Economics 106(2): 407-43.

Barro, R. 1996. Determinants of Economic Growth: A Cross-Country Empirical Study. NBER Working Paper No. 5698. Cambridge: National Bureau of Economic Research.

Barro, R. and X. Sala-i-Martin. 1992. Convergence. Journal of Political Economy 100(2): 223-251.

Bulman, D., M. Eden, and H. Nguyen. 2014. Transitioning from Low-Income Growth to High-Income Growth: Is there a Middle-Income Trap? World Bank Policy Research Working Paper No. 7104. Washington, DC: World Bank.

Cohen, D. 1996. Tests of the "Convergence Hypothesis": Some Further Results, Journal of Economic Growth, 1: 351-361.

Eichengreen, B., D. Park, and K. Shin. 2011. When Fast Growing Economies Slow Down: International Evidence and Implications for China. Asian Economic Papers 11(1): 42-87.

Eichengreen, B., D. Park, and K. Shin. 2014. Growth Slowdowns Redux. Japan and the World Economy, 32: 65-84.

European Commission. 2004. Catching-Up, Growth and Convergence of New Member States. Chapter 2 in The European Union Economy: 2004 Review. Brussels: European Commission.

Felipe, J., A. Abdon, and U. Kumar. 2012. Tracking the Middle-Income Trap: What is It, Who is In It, and Why? Working Paper 715 (April). New York: Levy Economics Institute of Bard College.

Felipe, J., U. Kumar, and R. Galope. 2017. Middle-Income Transition: Trap or Myth? Journal of the Asia Pacific Economy, (Forthcoming).

Freedom House. (https://freedomhouse.org/report/freedom-world/freedom-world-2016).

Ghosh, A. and U. Ramakrishnan. 2012. Current Account Deficits: Is There a Problem? Finance and Development. Washington, DC: International Monetary Fund.

Gill, I. and H. Kharas. 2007. An East Asian Renaissance. Washington, DC: World Bank.

Gill, I. and H. Kharas. 2015. The Middle-Income Trap Turns Ten. Policy Research Working Paper No. 7403. Washington, DC: World Bank.

Glawe, L. and H. Wagner. 2016. The Middle-Income Trap-Definitions, Theories, and Countries Concerned: A Literature Survey. Mimeo. University of Hagen. 
Han, X. and S.-J. Wei. 2017. Re-Examining the Middle-Income Trap Hypothesis: What to Reject and What to Revive. Journal of International Money and Finance, 73(A): 41-61.

Howitt, P. and P. Aghion. 1998. Capital Accumulation and Innovation as Complementary Factors in Long-Run Growth, Journal of Economic Growth, 3(2): 111-130

Im, F. G. and D. Rosenblatt. 2015. Middle-Income Traps: A Conceptual and Empirical Survey. Journal of International Commerce, Economics, and Policy, 6(3).

Ito, T. 2017. Growth Convergence and the Middle-Income Trap. Asian Development Review, 34(1): $1-27$.

Lane, P. and G. M. Milesi-Ferretti. 2011. External Wealth of Nations: Mark II. Journal of International Economics 73: 223-250.

Mankiw, G., D. Romer, and D. Weil. 1992. A Contribution to the Empirics of Growth. Quarterly Journal of Economics 107(2): 407-37.

Merriam-Webster Dictionary Online. (https://www.merriam-webster.com/).

National Center for Education Statistics. Trends in International Mathematics and Science Study. TIMSS International Data Explorer. (https://nces.ed.gov/timss/idetimss/).

Ozawa, T. 2005. Asia's Labor-Driven Economic Development, Flying-Geese Style: An Unprecedented Opportunity for Poor to Rise. APEC Study Center Discussion Paper No. 40. Columbia University.

Penn World Table 8.0. (http://www.rug.nl/ggdc/). Accessed January 2017.

Romer, P. 1990. Human Capital and Growth: Theory and Evidence. Carnegie-Rochester Conference Series on Public Policy 32(1): 251-286.

Sachs, J. and A. Warner. 1995. Natural Resource Abundance and Economic Growth. NBER Working Paper No. 5398. Cambridge: National Bureau of Economic Research.

Solow, R. 1956. A Contribution to the Theory of Economic Growth. Quarterly Journal of Economics, 70(1): 65-94.

Solow, R. and P. Samuelson. 1953. Balanced Growth under Constant Returns to Scale. Econometrica 21(3): 412-424.

Stokey, N. 2015. Catching Up and Falling Behind. Journal of Economic Growth, 20(1): 1-36.

Swan, T. W. 1956. Economic Growth and Capital Accumulation. Economic Record, 32(2): 334-361.

World Bank. World Development Indicators Online.

(http://databank.worldbank.org/data/reports.aspx?source=world-development-indicators). 
Figure 1: Average Per Capita Income $(\$)$

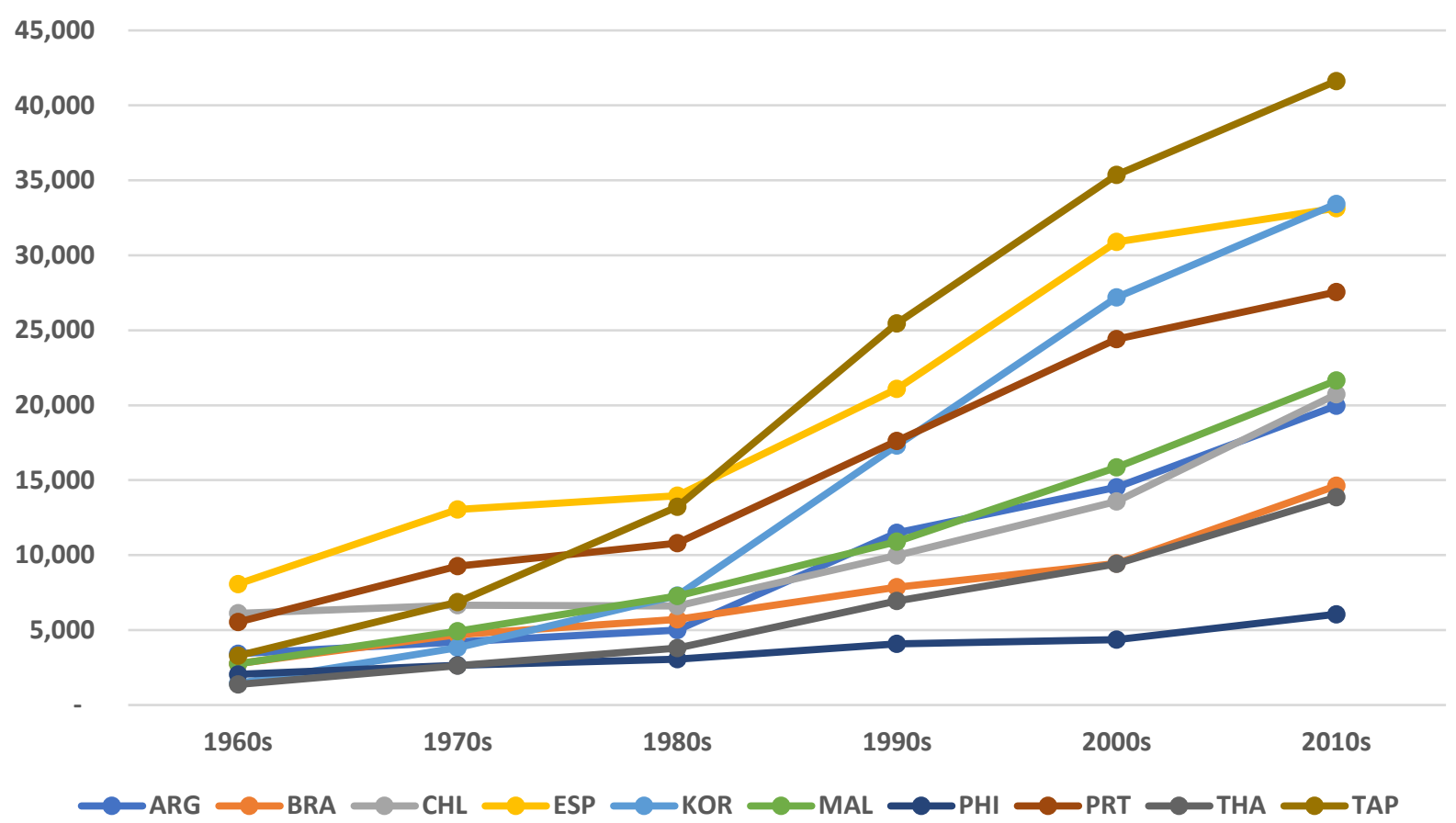

Notes: Values refer to the decade average of real GDP per capita at constant US dollar purchasing power parity. Data for 2010 s refer to average per capita income from 2010 to 2014. ARG = Argentina; $B R A=$ Brazil; $C H L=C h i l e ; E S P=S p a i n ;$ $\mathrm{KOR}=$ Korea, Rep. of; MAL = Malaysia; $\mathrm{PHI}=$ Philippines; $\mathrm{PRT}=$ Portugal; $\mathrm{THA}=$ Thailand; and TAP = Taipei,China . Source: Penn World Tables 8.0 accessed January 2017. 
Figure 2: Income Relative to Top Quintile in 1960s and 2010s
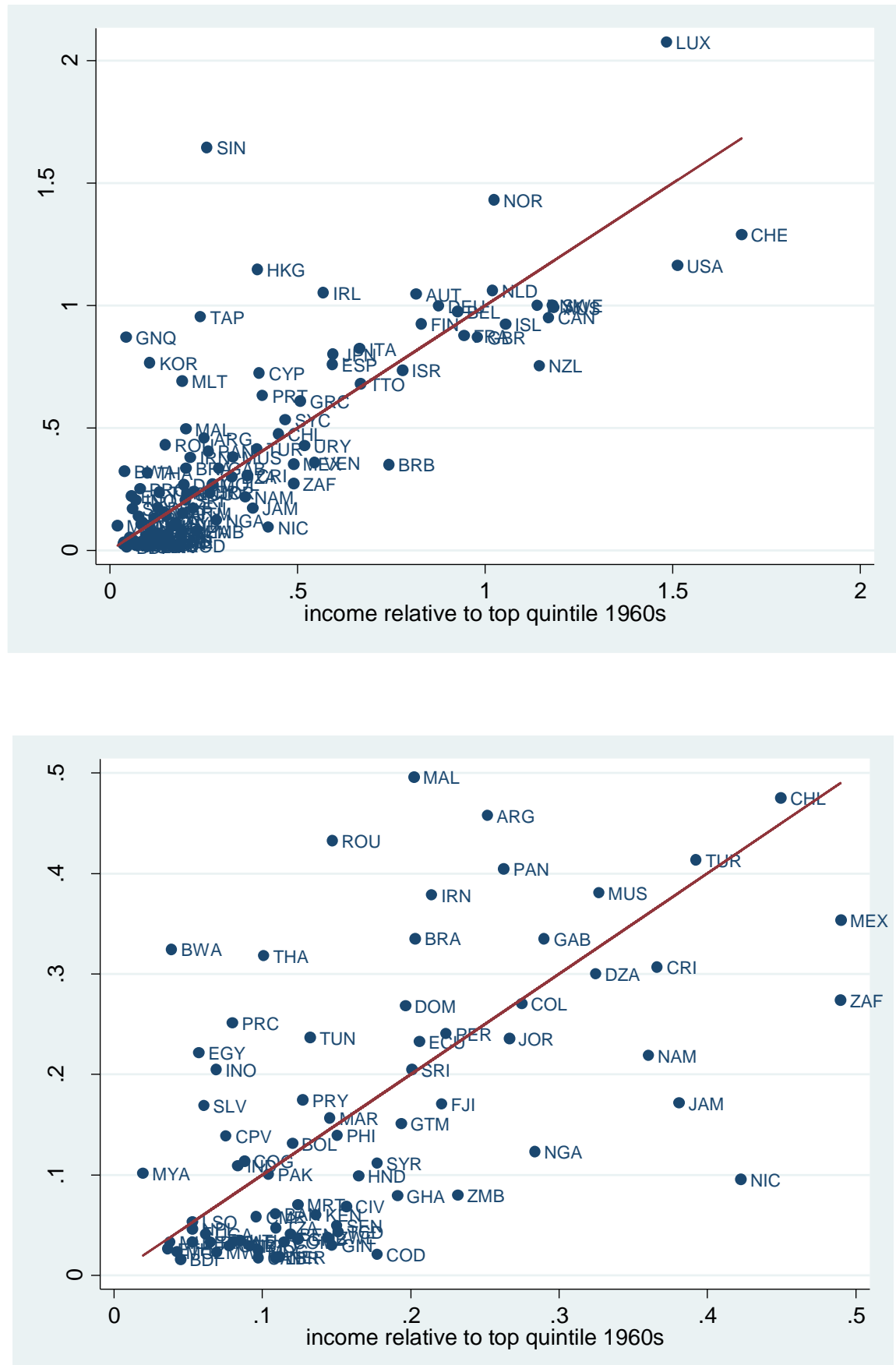

Notes: Values refer to individual country average per capita income relative to the average real income of the median country in the top $\left(5^{\text {th }}\right)$ quintile group in $1960 \mathrm{~s}$ and 2010s. The second panel zooms in to 0.5 values for both axes. 2010 s refer to average values from 2010 to 2014. Data are based on decade average values of real GDP per capita at constant US dollar purchasing power parity.

Source: Data based on Penn World Tables 8.0 accessed January 2017. 
Table 1: Per Capita Income Quintile Classifications

\begin{tabular}{|c|c|c|c|c|c|c|c|}
\hline Economies & Code & $1960 \mathrm{~s}$ & 1970s & $1980 \mathrm{~s}$ & 1990s & 2000 s & $2010 s$ \\
\hline Albania & ALB & $\ldots$ & 3 & 3 & 2 & 3 & 3 \\
\hline Algeria & DZA & 4 & 4 & 4 & 3 & 3 & 3 \\
\hline Angola & AGO & $\ldots$ & 3 & 2 & 2 & 2 & 2 \\
\hline Anguilla & AIA & $\ldots$ & 4 & 4 & 5 & 4 & 4 \\
\hline Antigua and Barbuda & ATG & $\ldots$ & 3 & 4 & 4 & 4 & 4 \\
\hline Argentina & ARG & 3 & 3 & 3 & 4 & 4 & 4 \\
\hline Armenia & ARM & $\ldots$ & $\ldots$ & $\ldots$ & 2 & 2 & 2 \\
\hline Aruba & $A B W$ & $\ldots$ & 4 & 5 & 5 & 5 & 5 \\
\hline Australia & AUS & 5 & 5 & 5 & 5 & 5 & 5 \\
\hline Austria & AUT & 5 & 5 & 5 & 5 & 5 & 5 \\
\hline Azerbaijan & AZE & $\ldots$ & $\ldots$ & $\ldots$ & 2 & 2 & 3 \\
\hline Bahamas & BHS & $\ldots$ & 4 & 5 & 5 & 4 & 4 \\
\hline Bahrain & BHR & $\ldots$ & 5 & 4 & 4 & 5 & 5 \\
\hline Bangladesh & BAN & 2 & 1 & 1 & 1 & 1 & 1 \\
\hline Barbados & BRB & 5 & 5 & 4 & 4 & 4 & 3 \\
\hline Belarus & BLR & $\ldots$ & $\ldots$ & $\ldots$ & 4 & 3 & 4 \\
\hline Belgium & BEL & 5 & 5 & 5 & 5 & 5 & 5 \\
\hline Belize & BLZ & $\ldots$ & 3 & 3 & 3 & 3 & 2 \\
\hline Benin & BEN & 2 & 2 & 1 & 1 & 1 & 1 \\
\hline Bermuda & BMU & $\ldots$ & 5 & 5 & 5 & 5 & 5 \\
\hline Bhutan & BTN & $\ldots$ & 1 & 2 & 2 & 2 & 2 \\
\hline Bolivia & $\mathrm{BOL}$ & 2 & 2 & 2 & 2 & 2 & 2 \\
\hline Bosnia \& Herzegovina & $\mathrm{BIH}$ & $\ldots$ & $\ldots$ & $\ldots$ & 2 & 3 & 2 \\
\hline Botswana & BWA & 1 & 1 & 3 & 3 & 3 & 3 \\
\hline Brazil & BRA & 3 & 3 & 3 & 3 & 3 & 3 \\
\hline British Virgin Islands & VGB & $\ldots$ & 4 & 4 & 5 & 5 & 4 \\
\hline Brunei Darussalam & BRN & $\ldots$ & 5 & 5 & 5 & 5 & 5 \\
\hline Bulgaria & BGR & $\ldots$ & 4 & 4 & 4 & 3 & 3 \\
\hline Burkina Faso & BFA & 1 & 1 & 1 & 1 & 1 & 1 \\
\hline Burundi & $\mathrm{BDI}$ & 1 & 1 & 1 & 1 & 1 & 1 \\
\hline Cabo Verde & $\mathrm{CPV}$ & 1 & 1 & 2 & 2 & 2 & 2 \\
\hline Cambodia & CAM & $\ldots$ & 1 & 1 & 1 & 1 & 1 \\
\hline Cameroon & CMR & 2 & 2 & 2 & 2 & 2 & 1 \\
\hline Canada & CAN & 5 & 5 & 5 & 5 & 5 & 5 \\
\hline Cayman Islands & CYM & $\ldots$ & 5 & 5 & 5 & 5 & 5 \\
\hline Central African Rep. & $\mathrm{CAF}$ & 2 & 1 & 1 & 1 & 1 & 1 \\
\hline Chad & TCD & 3 & 2 & 1 & 1 & 1 & 1 \\
\hline Chile & $\mathrm{CHL}$ & 4 & 4 & 3 & 4 & 4 & 4 \\
\hline China, People's Rep. of & PRC & 1 & 1 & 2 & 2 & 2 & 3 \\
\hline Colombia & $\mathrm{COL}$ & 4 & 3 & 3 & 3 & 3 & 3 \\
\hline Comoros & COM & 2 & 2 & 2 & 2 & 1 & 1 \\
\hline Congo & COG & 1 & 2 & 2 & 1 & 2 & 2 \\
\hline Costa Rica & CRI & 4 & 4 & 3 & 4 & 3 & 3 \\
\hline Cote d'Ivoire & $\mathrm{CIV}$ & 3 & 2 & 2 & 2 & 1 & 1 \\
\hline Croatia & HRV & $\ldots$ & $\ldots$ & $\ldots$ & 4 & 4 & 4 \\
\hline Curacao & cuW & $\ldots$ & $\ldots$ & $\ldots$ & $\ldots$ & 4 & 4 \\
\hline Cyprus & CYP & 4 & 4 & 4 & 5 & 5 & 4 \\
\hline Czech Republic & CZE & $\ldots$ & $\ldots$ & $\ldots$ & 4 & 4 & 4 \\
\hline D.R. of the Congo & COD & 3 & 2 & 2 & 1 & 1 & 1 \\
\hline
\end{tabular}


Table 1 (Continued)

\begin{tabular}{|c|c|c|c|c|c|c|c|}
\hline Economies & Code & $1960 \mathrm{~s}$ & 1970 s & $1980 \mathrm{~s}$ & $1990 \mathrm{~s}$ & $2000 \mathrm{~s}$ & $2010 \mathrm{~s}$ \\
\hline Denmark & DNK & 5 & 5 & 5 & 5 & 5 & 5 \\
\hline Djibouti & DJI & $\ldots$ & 4 & 3 & 2 & 2 & 1 \\
\hline Dominica & DMA & $\ldots$ & 3 & 3 & 3 & 3 & 3 \\
\hline Dominican Republic & DOM & 3 & 3 & 3 & 3 & 3 & 3 \\
\hline Ecuador & ECU & 3 & 3 & 3 & 3 & 3 & 3 \\
\hline Egypt & EGY & 1 & 1 & 1 & 2 & 2 & 3 \\
\hline El Salvador & SLV & 1 & 1 & 1 & 1 & 2 & 2 \\
\hline Equatorial Guinea & GNQ & 1 & 1 & 1 & 1 & 4 & 5 \\
\hline Estonia & EST & $\ldots$ & $\ldots$ & $\ldots$ & 4 & 4 & 4 \\
\hline Ethiopia & ETH & 1 & 1 & 1 & 1 & 1 & 1 \\
\hline Fiji & $\mathrm{FJI}$ & 3 & 3 & 3 & 3 & 3 & 2 \\
\hline Finland & FIN & 5 & 5 & 5 & 5 & 5 & 5 \\
\hline France & FRA & 5 & 5 & 5 & 5 & 5 & 5 \\
\hline Gabon & GAB & 4 & 4 & 4 & 4 & 4 & 3 \\
\hline Gambia & GMB & 2 & 2 & 2 & 2 & 1 & 1 \\
\hline Georgia & GEO & $\ldots$ & ... & $\ldots$ & 3 & 2 & 2 \\
\hline Germany & DEU & 5 & 5 & 5 & 5 & 5 & 5 \\
\hline Ghana & GHA & 3 & 2 & 2 & 2 & 2 & 2 \\
\hline Greece & GRC & 4 & 4 & 4 & 4 & 4 & 4 \\
\hline Grenada & GRD & $\ldots$ & 2 & 2 & 3 & 3 & 3 \\
\hline Guatemala & GTM & 3 & 3 & 3 & 2 & 2 & 2 \\
\hline Guinea & GIN & 2 & 2 & 2 & 2 & 1 & 1 \\
\hline Guinea-Bissau & GNB & 1 & 1 & 1 & 1 & 1 & 1 \\
\hline Haiti & HTI & 1 & 1 & 1 & 1 & 1 & 1 \\
\hline Honduras & HND & 3 & 2 & 2 & 2 & 2 & 2 \\
\hline Hong Kong, China & HKG & 4 & 4 & 5 & 5 & 5 & 5 \\
\hline Hungary & HUN & $\ldots$ & 4 & 4 & 4 & 4 & 4 \\
\hline Iceland & ISL & 5 & 5 & 5 & 5 & 5 & 5 \\
\hline India & IND & 1 & 1 & 1 & 1 & 2 & 2 \\
\hline Indonesia & INO & 1 & 1 & 2 & 2 & 2 & 2 \\
\hline Iran & IRN & 3 & 4 & 2 & 3 & 4 & 3 \\
\hline Iraq & IRQ & $\cdots$ & 3 & 3 & 2 & 2 & 3 \\
\hline Ireland & IRL & 4 & 4 & 4 & 5 & 5 & 5 \\
\hline Israel & ISR & 5 & 5 & 5 & 5 & 5 & 4 \\
\hline Italy & ITA & 5 & 5 & 5 & 5 & 5 & 5 \\
\hline Jamaica & JAM & 4 & 3 & 3 & 3 & 3 & 2 \\
\hline Japan & JPN & 5 & 5 & 5 & 5 & 5 & 5 \\
\hline Jordan & JOR & 4 & 3 & 3 & 2 & 2 & 3 \\
\hline Kazakhstan & $\mathrm{KAZ}$ & $\ldots$ & $\ldots$ & $\ldots$ & 3 & 3 & 4 \\
\hline Kenya & KEN & 2 & 2 & 2 & 2 & 1 & 1 \\
\hline Korea, Rep. of & KOR & 2 & 3 & 4 & 4 & 4 & 5 \\
\hline Kuwait & KWT & $\cdots$ & 5 & 5 & 5 & 5 & 5 \\
\hline Kyrgyzstan & KGZ & $\ldots$ & $\ldots$ & $\ldots$ & 2 & 1 & 1 \\
\hline Lao People's DR & LAO & $\ldots$ & 1 & 1 & 1 & 2 & 2 \\
\hline Latvia & LVA & $\cdots$ & $\cdots$ & $\cdots$ & 4 & 4 & 4 \\
\hline Lebanon & LBN & $\ldots$ & 3 & 3 & 3 & 3 & 3 \\
\hline Lesotho & LSO & 1 & 1 & 1 & 1 & 1 & 1 \\
\hline Liberia & LBR & 2 & 2 & 1 & 1 & 1 & 1 \\
\hline Lithuania & LTU & $\ldots$ & $\ldots$ & $\ldots$ & 4 & 4 & 4 \\
\hline
\end{tabular}


Table 1 (Continued)

\begin{tabular}{|c|c|c|c|c|c|c|c|}
\hline Economies & Code & 1960s & 1970 s & $1980 \mathrm{~s}$ & 1990s & $2000 \mathrm{~s}$ & 2010s \\
\hline Luxembourg & LUX & 5 & 5 & 5 & 5 & 5 & 5 \\
\hline Macao, China & MAC & $\ldots$ & 4 & 5 & 5 & 5 & 5 \\
\hline Macedonia & MKD & $\ldots$ & $\ldots$ & $\ldots$ & 3 & 3 & 3 \\
\hline Madagascar & MDG & 2 & 1 & 1 & 1 & 1 & 1 \\
\hline Malawi & MWI & 1 & 1 & 1 & 1 & 1 & 1 \\
\hline Malaysia & MAL & 3 & 3 & 4 & 4 & 4 & 4 \\
\hline Maldives & MDV & $\ldots$ & 2 & 2 & 3 & 3 & 3 \\
\hline Mali & MLI & 1 & 1 & 1 & 1 & 1 & 1 \\
\hline Malta & MLT & 3 & 4 & 4 & 4 & 4 & 4 \\
\hline Mauritania & MRT & 2 & 2 & 2 & 2 & 2 & 1 \\
\hline Mauritius & MUS & 4 & 3 & 3 & 4 & 4 & 3 \\
\hline Mexico & MEX & 4 & 4 & 4 & 4 & 4 & 3 \\
\hline Moldova & MDA & $\ldots$ & $\ldots$ & $\ldots$ & 2 & 2 & 2 \\
\hline Mongolia & MNG & $\ldots$ & 1 & 2 & 2 & 2 & 3 \\
\hline Montenegro & MNE & $\ldots$ & $\ldots$ & $\ldots$ & 3 & 3 & 3 \\
\hline Montserrat & MSR & $\ldots$ & 4 & 4 & 4 & 4 & 4 \\
\hline Morocco & MAR & 2 & 2 & 2 & 3 & 2 & 2 \\
\hline Mozambique & MOZ & 1 & 1 & 1 & 1 & 1 & 1 \\
\hline Myanmar & MYA & 1 & 1 & 1 & 1 & 1 & 2 \\
\hline Namibia & NAM & 4 & 3 & 3 & 3 & 3 & 3 \\
\hline Nepal & NPL & 1 & 1 & 1 & 1 & 1 & 1 \\
\hline Netherlands & NLD & 5 & 5 & 5 & 5 & 5 & 5 \\
\hline New Zealand & NZL & 5 & 5 & 5 & 5 & 4 & 4 \\
\hline Nicaragua & NIC & 4 & 4 & 3 & 2 & 2 & 2 \\
\hline Niger & NER & 2 & 1 & 1 & 1 & 1 & 1 \\
\hline Nigeria & NGA & 4 & 3 & 3 & 1 & 2 & 2 \\
\hline Norway & NOR & 5 & 5 & 5 & 5 & 5 & 5 \\
\hline Oman & OMN & $\ldots$ & 4 & 4 & 4 & 4 & 5 \\
\hline Pakistan & PAK & 2 & 2 & 2 & 2 & 2 & 2 \\
\hline Panama & PAN & 3 & 3 & 3 & 3 & 3 & 3 \\
\hline Paraguay & PRY & 2 & 2 & 3 & 2 & 2 & 2 \\
\hline Peru & PER & 3 & 3 & 3 & 3 & 3 & 3 \\
\hline Philippines & $\mathrm{PHI}$ & 3 & 2 & 2 & 2 & 2 & 2 \\
\hline Poland & POL & $\ldots$ & 4 & 4 & 4 & 4 & 4 \\
\hline Portugal & PRT & 4 & 4 & 4 & 4 & 4 & 4 \\
\hline Qatar & QAT & $\cdots$ & 5 & 5 & 5 & 5 & 5 \\
\hline Romania & ROU & 2 & 3 & 3 & 3 & 3 & 4 \\
\hline Russian Federation & RUS & $\ldots$ & $\ldots$ & $\ldots$ & 4 & 4 & 4 \\
\hline Rwanda & RWA & 1 & 1 & 1 & 1 & 1 & 1 \\
\hline Saint Kitts and Nevis & KNA & $\ldots$ & 3 & 4 & 4 & 4 & 4 \\
\hline Saint Lucia & LCA & $\ldots$ & 3 & 3 & 3 & 3 & 3 \\
\hline Sao Tome and Principe & STP & $\ldots$ & 2 & 2 & 2 & 1 & 1 \\
\hline Saudi Arabia & SAU & $\ldots$ & 5 & 5 & 4 & 4 & 5 \\
\hline Senegal & SEN & 3 & 2 & 2 & 2 & 1 & 1 \\
\hline Serbia & SRB & $\ldots$ & $\ldots$ & $\ldots$ & 3 & 3 & 3 \\
\hline Seychelles & SYC & 4 & 4 & 4 & 4 & 4 & 4 \\
\hline Sierra Leone & SLE & 1 & 1 & 1 & 1 & 1 & 1 \\
\hline Singapore & SIN & 3 & 4 & 4 & 5 & 5 & 5 \\
\hline Sint Maarten (Dutch) & SXM & $\ldots$ & $\ldots$ & $\ldots$ & $\ldots$ & 5 & 5 \\
\hline
\end{tabular}


Table 1 (Continued)

\begin{tabular}{|c|c|c|c|c|c|c|c|}
\hline Economies & Code & 1960s & 1970 s & $1980 \mathrm{~s}$ & $1990 \mathrm{~s}$ & 2000s & 2010s \\
\hline Slovakia & SVK & $\ldots$ & $\ldots$ & $\ldots$ & 4 & 4 & 4 \\
\hline Slovenia & SVN & $\ldots$ & $\ldots$ & $\ldots$ & 4 & 4 & 4 \\
\hline South Africa & ZAF & 4 & 4 & 4 & 3 & 3 & 3 \\
\hline Spain & ESP & 4 & 5 & 4 & 4 & 5 & 4 \\
\hline Sri Lanka & SRI & 3 & 2 & 2 & 2 & 2 & 2 \\
\hline St. Vincent \& Grenadines & VCT & $\ldots$ & 3 & 3 & 3 & 3 & 2 \\
\hline Sudan & SDN & $\ldots$ & 1 & 1 & 1 & 1 & 2 \\
\hline Suriname & SUR & $\ldots$ & 3 & 3 & 3 & 3 & 3 \\
\hline Swaziland & SWZ & $\ldots$ & 2 & 3 & 3 & 3 & 2 \\
\hline Sweden & SWE & 5 & 5 & 5 & 5 & 5 & 5 \\
\hline Switzerland & $\mathrm{CHE}$ & 5 & 5 & 5 & 5 & 5 & 5 \\
\hline Syria & SYR & 3 & 3 & 2 & 1 & 2 & 2 \\
\hline Taipei,China & TAP & 3 & 4 & 4 & 5 & 5 & 5 \\
\hline Tajikistan & TJK & $\ldots$ & $\ldots$ & $\ldots$ & 2 & 1 & 1 \\
\hline Tanzania & TZA & 2 & 2 & 1 & 1 & 1 & 1 \\
\hline Thailand & THA & 2 & 2 & 3 & 3 & 3 & 3 \\
\hline Togo & TGO & 2 & 2 & 1 & 1 & 1 & 1 \\
\hline Trinidad and Tobago & тाО & 5 & 5 & 4 & 4 & 4 & 4 \\
\hline Tunisia & TUN & 2 & 3 & 3 & 3 & 3 & 3 \\
\hline Turkey & TUR & 4 & 4 & 4 & 4 & 4 & 4 \\
\hline Turkmenistan & TKM & $\ldots$ & $\ldots$ & $\ldots$ & 3 & 3 & 4 \\
\hline Turks and Caicos & TCA & $\ldots$ & 3 & 4 & 4 & 4 & 4 \\
\hline Uganda & UGA & 1 & 1 & 1 & 1 & 1 & 1 \\
\hline Ukraine & UKR & $\ldots$ & $\ldots$ & $\ldots$ & 3 & 3 & 3 \\
\hline United Arab Emirates & ARE & $\ldots$ & 5 & 5 & 5 & 5 & 5 \\
\hline United Kingdom & GBR & 5 & 5 & 5 & 5 & 5 & 5 \\
\hline United States & USA & 5 & 5 & 5 & 5 & 5 & 5 \\
\hline Uruguay & URY & 4 & 4 & 4 & 4 & 3 & 4 \\
\hline Uzbekistan & UZB & $\ldots$ & $\ldots$ & $\ldots$ & 3 & 2 & 2 \\
\hline Venezuela & VEN & 4 & 4 & 4 & 3 & 3 & 3 \\
\hline Viet Nam & VNM & $\ldots$ & 1 & 1 & 1 & 2 & 2 \\
\hline West Bank and Gaza & PSE & $\ldots$ & 2 & 2 & 2 & 2 & 2 \\
\hline Yemen & YEM & $\ldots$ & $\ldots$ & 1 & 1 & 2 & 2 \\
\hline Zambia & ZMB & 3 & 2 & 2 & 1 & 1 & 2 \\
\hline Zimbabwe & ZWE & 2 & 2 & 2 & 3 & 1 & 1 \\
\hline
\end{tabular}

Notes: ... = data unavailable. 1 refers to the bottom quintile or bottom $20 \%$ of income groups. 5 refers to the top quintile or top $20 \%$ of income groups. Data based on decade average values of real GDP per capita at constant US dollar purchasing power parity. Data for 2010 refer to the average values from 2010 to 2014.

Source: Authors' calculations using Penn World Tables 8.0 accessed January 2017. 
Table 2: Statistics for Quintile Income Grouping in the 2010s

\begin{tabular}{ccrrrrrr}
\hline \hline Quintile & Obs & \multicolumn{1}{c}{ Min } & \multicolumn{1}{c}{ Max } & Mean & Median & \multicolumn{1}{c}{ SD } & \multicolumn{1}{c}{ CoV } \\
\hline 1 & 37 & 701 & 3,231 & 1,787 & 1,568 & 751 & 0.420 \\
2 & 36 & 3,445 & 9,400 & 6,147 & 6,050 & 1,851 & 0.301 \\
3 & 37 & 9,550 & 17,652 & 12,833 & 12,699 & 2,439 & 0.190 \\
4 & 36 & 17,805 & 33,144 & 24,373 & 23,586 & 4,671 & 0.192 \\
5 & 36 & 33,428 & 147,749 & 52,849 & 43,613 & 23,270 & 0.440 \\
\hline \hline
\end{tabular}

Notes: Obs = number of countries in the quintile income group. Min = minimum; Max = maximum; $\mathrm{SD}=$ standard deviation; and $\mathrm{CoV}=$ coefficient of variable. Data based on decade average values of real GDP per capita at constant US dollar purchasing power parity.

Source: Authors' calculations using Penn World Tables 8.0 accessed January 2017. 
Table 3: Transitions to Higher Quintile Income Groups

\begin{tabular}{|c|c|c|c|c|c|}
\hline Quintile & 1970s & 1980s & 1990s & $2000 s$ & 2010s \\
\hline 2nd Quintile & Congo, Rep. of & $\begin{array}{l}\text { Bhutan } \\
\text { Cabo Verde } \\
\text { China, People's Rep. of } \\
\text { Indonesia } \\
\text { Mongolia }\end{array}$ & Egypt & $\begin{array}{l}\text { Congo, Rep. of } \\
\text { El Salvador } \\
\text { India } \\
\text { Lao PDR } \\
\text { Nigeria } \\
\text { Syria } \\
\text { Viet Nam } \\
\text { Yemen }\end{array}$ & $\begin{array}{l}\text { Myanmar } \\
\text { Sudan } \\
\text { Zambia }\end{array}$ \\
\hline 3rd Quintile & $\begin{array}{l}\text { Korea, Rep. of } \\
\text { Romania } \\
\text { Tunisia }\end{array}$ & $\begin{array}{l}\text { Botswana } \\
\text { Paraguay } \\
\text { Swaziland } \\
\text { Thailand }\end{array}$ & $\begin{array}{l}\text { Grenada } \\
\text { Iran } \\
\text { Maldives } \\
\text { Morocco } \\
\text { Zimbabwe }\end{array}$ & $\begin{array}{l}\text { Albania } \\
\text { Bosnia \& Herzegovina }\end{array}$ & $\begin{array}{l}\text { Azerbaijan } \\
\text { China, People's Rep. of } \\
\text { Egypt } \\
\text { Iraq } \\
\text { Jordan } \\
\text { Mongolia }\end{array}$ \\
\hline 4th Quintile & $\begin{array}{l}\text { Iran } \\
\text { Malta } \\
\text { Singapore } \\
\text { Taipei,China }\end{array}$ & $\begin{array}{l}\text { Antigua \& Barbuda } \\
\text { Korea, Rep. of } \\
\text { Malaysia } \\
\text { Saint Kitts \& Nevis } \\
\text { Turks \& Caicos }\end{array}$ & $\begin{array}{l}\text { Argentina } \\
\text { Chile } \\
\text { Costa Rica } \\
\text { Mauritius }\end{array}$ & $\begin{array}{l}\text { Equatorial Guinea } \\
\text { Iran }\end{array}$ & $\begin{array}{l}\text { Belarus } \\
\text { Kazakhstan } \\
\text { Romania } \\
\text { Turkmenistan } \\
\text { Uruguay }\end{array}$ \\
\hline 5th Quntile & Spain & $\begin{array}{l}\text { Aruba } \\
\text { Bahamas } \\
\text { Hong Kong, China } \\
\text { Macau, China }\end{array}$ & $\begin{array}{l}\text { Anguilla } \\
\text { British Virgin Islands } \\
\text { Cyprus } \\
\text { Ireland } \\
\text { Singapore } \\
\text { Taipei,China }\end{array}$ & $\begin{array}{l}\text { Bahrain } \\
\text { Spain }\end{array}$ & $\begin{array}{l}\text { Equatorial Guinea } \\
\text { Korea, Rep. of } \\
\text { Oman } \\
\text { Saudi Arabia }\end{array}$ \\
\hline
\end{tabular}

Notes: The table lists the countries which moved to higher quintile income group by decade. For instance, Rep. of Korea moved from second quintile income group in 1960s to third quintile income group in the 1970s, to fourth quintile income group in the 1980s and to fifth quintile income group in 2010s. Data based on decade average values of real GDP per capita at constant US dollar purchasing power parity.

Source: Data based on country classifications shown in Table 1. 
Table 4: Determinants of Moving to a Higher Income Group

(regardless of which decade and quintile income grouping)

\begin{tabular}{|c|c|c|c|c|c|c|c|c|c|c|}
\hline \multirow[b]{2}{*}{ VARIABLES } & \multicolumn{2}{|c|}{ 1960s } & \multicolumn{2}{|c|}{ 1970s } & \multicolumn{2}{|c|}{$1980 \mathrm{~s}$} & \multicolumn{2}{|c|}{ 1990s } & \multicolumn{2}{|c|}{$2000 s$} \\
\hline & (1) & (2) & (3) & (4) & (5) & (6) & (7) & (8) & (9) & $(10)$ \\
\hline Per capita income & $\begin{array}{c}-0.389 * * * \\
(0.151)\end{array}$ & $\begin{array}{c}-0.206 \\
(0.175)\end{array}$ & $\begin{array}{c}-0.157^{* *} \\
(0.075)\end{array}$ & $\begin{array}{c}-0.326 * * \\
(0.152)\end{array}$ & $\begin{array}{c}-0.233^{* * *} \\
(0.075)\end{array}$ & $\begin{array}{c}-0.306 * * \\
(0.137)\end{array}$ & $\begin{array}{l}-0.119 \\
(0.072)\end{array}$ & $\begin{array}{l}-0.155 \\
(0.124)\end{array}$ & $\begin{array}{c}0.048 \\
(0.087)\end{array}$ & $\begin{array}{c}0.091 \\
(0.141)\end{array}$ \\
\hline Population growth & $\begin{array}{c}0.352 \\
(0.418)\end{array}$ & $\begin{array}{c}0.375 \\
(0.459)\end{array}$ & $\begin{array}{c}-0.220 \\
(0.174)\end{array}$ & $\begin{array}{c}-0.716 * * \\
(0.355)\end{array}$ & $\begin{array}{l}-0.249 \\
(0.201)\end{array}$ & $\begin{array}{c}-0.256 \\
(0.311)\end{array}$ & $\begin{array}{c}-0.269 \\
(0.181)\end{array}$ & $\begin{array}{c}0.054 \\
(0.327)\end{array}$ & $\begin{array}{c}-0.555^{* * *} \\
(0.180)\end{array}$ & $\begin{array}{c}-0.560 * * \\
(0.229)\end{array}$ \\
\hline Physical capital growth & $\begin{array}{c}0.666^{* * *} \\
(0.225)\end{array}$ & $\begin{array}{c}0.770 * * \\
(0.307)\end{array}$ & $\begin{array}{c}0.361^{* * *} \\
(0.136)\end{array}$ & $\begin{array}{c}0.878 * * * \\
(0.275)\end{array}$ & $\begin{array}{c}0.834^{* * *} \\
(0.172)\end{array}$ & $\begin{array}{c}0.820 * * * \\
(0.240)\end{array}$ & $\begin{array}{c}0.850^{* * *} \\
(0.146)\end{array}$ & $\begin{array}{c}0.934^{* * *} \\
(0.226)\end{array}$ & $\begin{array}{c}0.503 * * * \\
(0.133)\end{array}$ & $\begin{array}{c}0.474 * * \\
(0.214)\end{array}$ \\
\hline Productivity growth & & $\begin{array}{c}-0.012 \\
(0.021)\end{array}$ & & $\begin{array}{c}0.029 * * * \\
(0.010)\end{array}$ & & $\begin{array}{c}0.008 \\
(0.016)\end{array}$ & & $\begin{array}{c}0.013 \\
(0.013)\end{array}$ & & $\begin{array}{c}-0.005 \\
(0.010)\end{array}$ \\
\hline Human capital growth & & $\begin{array}{c}-0.017 \\
(0.069)\end{array}$ & & $\begin{array}{c}0.094 * * * \\
(0.036)\end{array}$ & & $\begin{array}{c}0.090 * * * \\
(0.032)\end{array}$ & & $\begin{array}{l}0.092 * \\
(0.052)\end{array}$ & & $\begin{array}{c}0.068 \\
(0.047)\end{array}$ \\
\hline Civil liberties & $\begin{array}{c}-0.035 \\
(0.154)\end{array}$ & $\begin{array}{l}-0.239 \\
(0.181)\end{array}$ & $\begin{array}{c}-0.091 \\
(0.104)\end{array}$ & $\begin{array}{c}-0.338 * * \\
(0.172)\end{array}$ & $\begin{array}{l}-0.067 \\
(0.107)\end{array}$ & $\begin{array}{c}-0.086 \\
(0.177)\end{array}$ & $\begin{array}{c}-0.166 \\
(0.110)\end{array}$ & $\begin{array}{c}-0.284 \\
(0.178)\end{array}$ & $\begin{array}{c}-0.304^{* *} \\
(0.132)\end{array}$ & $\begin{array}{c}-0.456 * * \\
(0.199)\end{array}$ \\
\hline S-I gap & $\begin{array}{c}-0.004 \\
(0.029)\end{array}$ & $\begin{array}{c}0.025 \\
(0.069)\end{array}$ & $\begin{array}{c}0.012 \\
(0.015)\end{array}$ & $\begin{array}{l}-0.022 \\
(0.025)\end{array}$ & $\begin{array}{c}-0.011 \\
(0.007)\end{array}$ & $\begin{array}{l}-0.000 \\
(0.020)\end{array}$ & $\begin{array}{l}0.022 * \\
(0.012)\end{array}$ & $\begin{array}{c}0.080 * * \\
(0.036)\end{array}$ & $\begin{array}{c}0.012 \\
(0.011)\end{array}$ & $\begin{array}{l}0.044^{* *} \\
(0.018)\end{array}$ \\
\hline Oil share & $\begin{array}{c}1.818 \\
(2.096)\end{array}$ & $\begin{array}{c}1.312 \\
(2.146)\end{array}$ & $\begin{array}{c}0.023 \\
(0.033)\end{array}$ & $\begin{array}{c}0.131^{* *} \\
(0.053)\end{array}$ & $\begin{array}{c}0.075^{* * *} \\
(0.025)\end{array}$ & $\begin{array}{c}0.052 \\
(0.052)\end{array}$ & $\begin{array}{c}0.029 \\
(0.019)\end{array}$ & $\begin{array}{l}-0.017 \\
(0.029)\end{array}$ & $\begin{array}{c}0.024 \\
(0.017)\end{array}$ & $\begin{array}{c}-0.034 \\
(0.031)\end{array}$ \\
\hline Inflation volatility & $\begin{array}{c}0.089 * * * \\
(0.034)\end{array}$ & $\begin{array}{c}0.072 * * \\
(0.033)\end{array}$ & $\begin{array}{c}0.022^{* * *} \\
(0.007)\end{array}$ & $\begin{array}{c}0.040 * * * \\
(0.011)\end{array}$ & $\begin{array}{c}0.005 \\
(0.005)\end{array}$ & $\begin{array}{c}0.005 \\
(0.005)\end{array}$ & $\begin{array}{l}-0.000 \\
(0.002)\end{array}$ & $\begin{array}{l}-0.001 \\
(0.005)\end{array}$ & $\begin{array}{l}-0.039 \\
(0.027)\end{array}$ & $\begin{array}{l}-0.000 \\
(0.042)\end{array}$ \\
\hline No. of movers & 22 & 18 & 49 & 28 & 52 & 35 & 59 & 36 & 59 & 37 \\
\hline Observations & 81 & 55 & 141 & 80 & 148 & 100 & 172 & 115 & 174 & 116 \\
\hline
\end{tabular}

Notes: In these probit regressions, the dependent variable pertains to a dummy variable which takes a value of 1 if a country has moved to a higher quintile income group regardless of which quintile income group it belongs and regardless of which decade the transition occurred; and 0 otherwise. Per capita income refers to log value of real GDP per capita. Population, physical capital, productivity, human capital growth rates refer to within decade growth rates. Civil liberties is an index. SI Gap, or saving-investment gap, and oil share are in percent of GDP. Inflation volatility refers to within decade standard deviation of inflation. Robust standard errors are used. ${ }^{* *},{ }^{* *}$, and * significant at $1 \%, 5 \%$ and $10 \%$, respectively.

Source: Authors' estimates. 
Table 5: Determinants of Moving to a Higher Income Group

(regardless of quintile income grouping)

\begin{tabular}{|c|c|c|c|c|c|c|c|c|c|c|}
\hline \multirow[b]{2}{*}{ VARIABLES } & \multicolumn{2}{|c|}{ 1960s } & \multicolumn{2}{|c|}{ 1970s } & \multicolumn{2}{|c|}{$1980 s$} & \multicolumn{2}{|c|}{ 1990s } & \multicolumn{2}{|c|}{$2000 s$} \\
\hline & $(1)$ & $(2)$ & (3) & (4) & (5) & $(6)$ & (7) & $(8)$ & (9) & $(10)$ \\
\hline \multirow[t]{2}{*}{ Per capita income } & $-0.394 * *$ & -0.561 & $-0.538 * * *$ & $-1.049 * *$ & $-0.520 * * *$ & $-0.364 *$ & $-0.405 * * *$ & $-0.461^{*}$ & -0.101 & -0.133 \\
\hline & (0.199) & $(0.464)$ & $(0.147)$ & $(0.481)$ & $(0.165)$ & $(0.194)$ & $(0.131)$ & $(0.246)$ & $(0.120)$ & $(0.159)$ \\
\hline \multirow[t]{2}{*}{ Population growth } & -0.522 & 0.270 & 0.048 & 0.736 & -0.164 & -0.246 & -0.486 & 0.033 & $-1.212^{* *}$ & $-0.943 * *$ \\
\hline & $(0.680)$ & $(1.220)$ & $(0.300)$ & $(0.704)$ & $(0.336)$ & $(0.463)$ & $(0.376)$ & $(0.949)$ & $(0.507)$ & $(0.474)$ \\
\hline \multirow[t]{2}{*}{ Physical capital growth } & $1.279 * * *$ & $1.267^{* * *}$ & $0.747^{* * *}$ & $1.005^{*}$ & $0.669 * *$ & 0.104 & $0.646 * *$ & 0.467 & $0.452 * *$ & $0.480 * *$ \\
\hline & $(0.424)$ & $(0.413)$ & $(0.207)$ & $(0.565)$ & $(0.294)$ & $(0.348)$ & $(0.255)$ & (0.315) & $(0.194)$ & $(0.221)$ \\
\hline \multirow[t]{2}{*}{ Productivity growth } & & 0.040 & & 0.035 & & 0.016 & & 0.002 & & 0.003 \\
\hline & & $(0.049)$ & & $(0.028)$ & & $(0.018)$ & & $(0.018)$ & & $(0.010)$ \\
\hline \multirow[t]{2}{*}{ Human capital growth } & & 0.177 & & $0.192^{*}$ & & 0.037 & & 0.075 & & -0.047 \\
\hline & & $(0.170)$ & & $(0.104)$ & & $(0.029)$ & & $(0.096)$ & & $(0.054)$ \\
\hline \multirow[t]{2}{*}{ Civil liberties } & $-0.566 * * *$ & $-0.872 * *$ & 0.208 & 0.131 & 0.256 & 0.113 & -0.152 & -0.165 & $-0.434^{* *}$ & -0.346 \\
\hline & $(0.196)$ & $(0.353)$ & $(0.183)$ & $(0.386)$ & $(0.228)$ & $(0.295)$ & $(0.231)$ & $(0.380)$ & $(0.220)$ & $(0.271)$ \\
\hline \multirow[t]{2}{*}{ S-I gap } & -0.053 & 0.070 & 0.047 & $0.140 * *$ & 0.009 & -0.010 & $-0.036^{*}$ & 0.015 & 0.018 & -0.020 \\
\hline & $(0.039)$ & $(0.198)$ & $(0.029)$ & $(0.061)$ & $(0.017)$ & $(0.040)$ & $(0.019)$ & $(0.046)$ & $(0.018)$ & $(0.034)$ \\
\hline \multirow[t]{2}{*}{ Oil share } & $5.822 *$ & 6.872 & -0.062 & -0.172 & 0.011 & 0.030 & $0.123^{* * *}$ & $0.077^{* *}$ & $0.049 * * *$ & $0.089 * * *$ \\
\hline & $(3.232)$ & $(6.831)$ & $(0.049)$ & $(0.148)$ & $(0.050)$ & $(0.066)$ & $(0.025)$ & $(0.036)$ & $(0.019)$ & $(0.032)$ \\
\hline \multirow[t]{2}{*}{ Inflation volatility } & 0.014 & -0.008 & -0.023 & 0.019 & 0.009 & 0.008 & $-0.011 * * *$ & -0.011 & 0.030 & 0.016 \\
\hline & $(0.013)$ & $(0.025)$ & $(0.038)$ & $(0.021)$ & $(0.006)$ & $(0.005)$ & $(0.003)$ & $(0.009)$ & $(0.028)$ & $(0.076)$ \\
\hline No. of movers & 6 & 5 & 15 & 7 & 14 & 12 & 14 & 6 & 18 & 11 \\
\hline Observations & 81 & 55 & 141 & 80 & 148 & 100 & 172 & 115 & 174 & 116 \\
\hline
\end{tabular}

Notes: In these probit regressions, the dependent variable pertains to a dummy variable which takes a value of 1 if a country has moved to a higher quintile income group in the following decade, regardless of which quintile income group it belongs in the current decade; and 0 otherwise. Per capita income refers to log value of real GDP per capita. Population, physical capital, productivity, human capital growth rates refer to within decade growth rates. Civil liberties is an index. S-I Gap, or saving-investment gap, or saving-investment gap, and oil share are in percent of GDP. Inflation volatility refers to within decade standard deviation of inflation. Robust standard errors are used. ${ }^{* * *},{ }^{* *}$, and ${ }^{*}$ significant at $1 \%, 5 \%$ and $10 \%$, respectively.

Source: Authors' estimates. 


\section{Table 6: Conditional Determinants of Moving to Higher Quintile Income Group}

Table 6a: 1960s

\begin{tabular}{|c|c|c|c|c|}
\hline & (1) & (2) & (3) & (4) \\
\hline VARIABLES & Quintile2 & Quintile3 & Quintile4 & Quintile5 \\
\hline \multirow[t]{2}{*}{ Population growth } & $\ldots$ & -0.284 & $-2.374 * * *$ & $-1.755^{* * *}$ \\
\hline & $\ldots$ & (1.993) & $(0.852)$ & $(0.606)$ \\
\hline \multirow[t]{2}{*}{ Physical capital growth } & $\ldots$ & $1.541^{*}$ & $2.660 * * *$ & $2.418^{* * *}$ \\
\hline & $\ldots$ & $(0.836)$ & $(0.534)$ & (0.892) \\
\hline \multirow[t]{2}{*}{ Oil share } & $\ldots$ & $151.897^{* *}$ & $-21.147^{* *}$ & -17.162 \\
\hline & $\ldots$ & $(67.905)$ & (9.058) & (39.911) \\
\hline No. of movers & $\ldots$ & 3 & 4 & 1 \\
\hline Observations & $\ldots$ & 22 & 23 & 23 \\
\hline
\end{tabular}

Table 6b: 1970s

\begin{tabular}{lcccc}
\hline \hline \multirow{4}{*}{ VARIABLES } & $\mathbf{( 1 )}$ & $\mathbf{( 2 )}$ & $\mathbf{( 3 )}$ & $\mathbf{( 4 )}$ \\
& Quintile2 & Quintile3 & Quintile4 & Quintile5 \\
\hline \multirow{3}{*}{ Population growth } & 0.983 & $-0.863^{*}$ & -0.517 & -0.201 \\
& $(2.110)$ & $(0.445)$ & $(0.926)$ & $(0.285)$ \\
Physical capital growth & $0.558^{*}$ & $1.767^{* * *}$ & $0.817^{*}$ & -0.170 \\
& $(0.289)$ & $(0.424)$ & $(0.494)$ & $(0.526)$ \\
Oil share & $0.311^{* *}$ & -19.360 & -0.163 & $\ldots$ \\
& $(0.143)$ & $(18.074)$ & $(0.144)$ & $\ldots$ \\
No. of movers & & & & \\
Observations & 6 & 3 & 5 & 4 \\
\hline \hline
\end{tabular}

Table 6c: 1980s

\begin{tabular}{lcccc}
\hline \hline \multirow{2}{*}{ VARIABLES } & $\begin{array}{c}(\mathbf{1}) \\
\text { Quintile2 }\end{array}$ & $\begin{array}{c}(\mathbf{2}) \\
\text { Quintile3 }\end{array}$ & $\begin{array}{c}\text { (3) } \\
\text { Quintile4 }\end{array}$ & $\begin{array}{c}\text { (4) } \\
\text { Quintile5 }\end{array}$ \\
\hline \multirow{3}{*}{ Population growth } & & & & \\
& $\ldots$ & 0.115 & -0.521 & 0.416 \\
Physical capital growth & $\ldots$ & $(0.845)$ & $(0.519)$ & $(0.281)$ \\
& $\ldots$ & $0.605^{*}$ & -0.646 & -0.270 \\
Oil share & $\ldots$ & $(0.356)$ & $(0.400)$ & $(0.372)$ \\
& $\ldots$ & -0.037 & -0.114 & $\ldots$ \\
No. of movers & $\ldots$ & $(0.074)$ & $(0.114)$ & $\ldots$ \\
Observations & & & & \\
\hline \hline
\end{tabular}


Table 6d: 1990s

\begin{tabular}{lcccc}
\hline \hline \multirow{4}{*}{ VARIABLES } & $\mathbf{( 1 )}$ & $\mathbf{( 2 )}$ & $\mathbf{( 3 )}$ & $\mathbf{( 4 )}$ \\
& Quintile2 & Quintile3 & Quintile4 & Quintile5 \\
\hline \multirow{4}{*}{ Population growth } & $-1.565^{*}$ & $-2.870^{* * *}$ & $\ldots$ & 3.235 \\
& $(0.865)$ & $(0.593)$ & $\ldots$ & $(2.348)$ \\
Physical capital growth & 0.576 & 0.278 & $\ldots$ & -3.550 \\
& $(0.365)$ & $(0.385)$ & $\ldots$ & $(2.555)$ \\
Oil share & 0.603 & $0.107^{* * *}$ & $\ldots$ & $-0.360^{*}$ \\
& $(0.552)$ & $(0.037)$ & $\ldots$ & $(0.197)$ \\
No. of movers & & & & \\
Observations & 9 & 2 & $\ldots$ & 2 \\
\hline
\end{tabular}

Table 6e: 2000s

\begin{tabular}{lcccc}
\hline \hline \multirow{4}{*}{ VARIABLES } & $\mathbf{( 1 )}$ & $\mathbf{( 2 )}$ & $\mathbf{( 3 )}$ & $\mathbf{( 4 )}$ \\
& Quintile2 & Quintile3 & Quintile4 & Quintile5 \\
\hline \multirow{4}{*}{ Population growth } & $-0.997^{*}$ & -0.360 & $-5.120^{* *}$ & $-1.560^{* * *}$ \\
& $(0.550)$ & $(0.852)$ & $(2.404)$ & $(0.500)$ \\
Physical capital growth & $0.889^{* *}$ & 0.461 & -0.463 & $1.703^{* * *}$ \\
& $(0.442)$ & $(0.412)$ & $(0.413)$ & $(0.484)$ \\
Oil share & 0.060 & 0.034 & $0.331^{* *}$ & $0.148^{* * *}$ \\
& $(0.060)$ & $(0.033)$ & $(0.162)$ & $(0.044)$ \\
No. of movers & & & & \\
Observations & 3 & 6 & 5 & 4 \\
\hline \hline
\end{tabular}

Notes: In these probit regressions, the dependent variable pertains to a dummy variable which takes a value of 1 if a country has moved to the next higher quintile income group in the following decade, conditional on being in a given quintile income group in the current decade; and 0 otherwise. Population, and physical capital refer to within decade growth rates. Oil share is in percent of GDP. Robust standard errors are used. ${ }^{* *}$, **, and * significant at $1 \%, 5 \%$ and $10 \%$, respectively.

Source: Authors' estimates. 
Table 7: Determinants of Moving to a Higher Income Group

(using interaction term between growth of capital-labor ratio and human capital)

\begin{tabular}{|c|c|c|c|c|c|c|c|c|c|c|}
\hline VARIABLES & $\begin{array}{c}1960 s \\
(1)\end{array}$ & $\begin{array}{c}1970 s \\
(2) \\
\end{array}$ & $\begin{array}{c}1980 s \\
(3) \\
\end{array}$ & $\begin{array}{c}1990 \mathrm{~s} \\
(4)\end{array}$ & $\begin{array}{c}2000 \mathrm{~s} \\
(5)\end{array}$ & $\begin{array}{c}1960 \mathrm{~s} \\
(6) \\
\end{array}$ & $\begin{array}{c}1970 \mathrm{~s} \\
(7) \\
\end{array}$ & $\begin{array}{c}1980 \mathrm{~s} \\
(8) \\
\end{array}$ & $\begin{array}{c}1990 \mathrm{~s} \\
(9) \\
\end{array}$ & $\begin{array}{c}2000 \mathrm{~s} \\
(10)\end{array}$ \\
\hline Per capita income & $\begin{array}{l}-0.013 \\
(0.137)\end{array}$ & $\begin{array}{c}-0.201^{*} \\
(0.110)\end{array}$ & $\begin{array}{c}-0.194 * * \\
(0.086)\end{array}$ & $\begin{array}{c}-0.070 \\
(0.123)\end{array}$ & $\begin{array}{c}0.069 \\
(0.106)\end{array}$ & $\begin{array}{l}-0.213 \\
(0.224)\end{array}$ & $\begin{array}{c}-0.603^{* *} \\
(0.298)\end{array}$ & $\begin{array}{c}-0.387^{* *} \\
(0.178)\end{array}$ & $\begin{array}{c}-0.412 \\
(0.276)\end{array}$ & $\begin{array}{l}-0.115 \\
(0.144)\end{array}$ \\
\hline Productivity Growth & $\begin{array}{l}-0.006 \\
(0.022)\end{array}$ & $\begin{array}{c}0.025^{* *} \\
(0.011)\end{array}$ & $\begin{array}{c}0.008 \\
(0.014)\end{array}$ & $\begin{array}{c}0.019 \\
(0.012)\end{array}$ & $\begin{array}{c}0.001 \\
(0.009)\end{array}$ & $\begin{array}{l}0.041^{*} \\
(0.024)\end{array}$ & $\begin{array}{c}0.025 \\
(0.021)\end{array}$ & $\begin{array}{c}0.018 \\
(0.019)\end{array}$ & $\begin{array}{c}0.000 \\
(0.016)\end{array}$ & $\begin{array}{c}0.009 \\
(0.011)\end{array}$ \\
\hline Interaction $\mathrm{K} / \mathrm{L} * \mathrm{HC}$ & $\begin{array}{c}0.029 \\
(0.050)\end{array}$ & $\begin{array}{c}0.113^{* * *} \\
(0.037)\end{array}$ & $\begin{array}{c}0.123^{* * *} \\
(0.032)\end{array}$ & $\begin{array}{c}0.138 * * * \\
(0.043)\end{array}$ & $\begin{array}{c}0.079 * * \\
(0.039)\end{array}$ & $\begin{array}{c}0.193^{* *} \\
(0.086)\end{array}$ & $\begin{array}{c}0.242^{* * *} \\
(0.082)\end{array}$ & $\begin{array}{c}0.034 \\
(0.026)\end{array}$ & $\begin{array}{c}0.105 \\
(0.067)\end{array}$ & $\begin{array}{c}-0.002 \\
(0.041)\end{array}$ \\
\hline Civil Liberties & $\begin{array}{l}-0.289 * \\
(0.172)\end{array}$ & $\begin{array}{c}-0.348^{* *} \\
(0.163)\end{array}$ & $\begin{array}{c}-0.156 \\
(0.145)\end{array}$ & $\begin{array}{l}-0.292 \\
(0.183)\end{array}$ & $\begin{array}{c}-0.403^{* *} \\
(0.164)\end{array}$ & $\begin{array}{c}-0.948 * * * \\
(0.338)\end{array}$ & $\begin{array}{c}-0.082 \\
(0.317)\end{array}$ & $\begin{array}{c}0.144 \\
(0.277)\end{array}$ & $\begin{array}{c}-0.184 \\
(0.410)\end{array}$ & $\begin{array}{c}-0.403 \\
(0.297)\end{array}$ \\
\hline S-I Gap & $\begin{array}{c}0.051 \\
(0.058)\end{array}$ & $\begin{array}{c}-0.043 \\
(0.030)\end{array}$ & $\begin{array}{c}0.010 \\
(0.020)\end{array}$ & $\begin{array}{c}0.057 * * \\
(0.026)\end{array}$ & $\begin{array}{c}0.037 * * \\
(0.015)\end{array}$ & $\begin{array}{c}0.058 \\
(0.095)\end{array}$ & $\begin{array}{l}0.129 * \\
(0.074)\end{array}$ & $\begin{array}{c}-0.008 \\
(0.040)\end{array}$ & $\begin{array}{c}0.012 \\
(0.035)\end{array}$ & $\begin{array}{l}-0.015 \\
(0.029)\end{array}$ \\
\hline Oil Share & $\begin{array}{c}0.609 \\
(2.053)\end{array}$ & $\begin{array}{c}0.099 \\
(0.061)\end{array}$ & $\begin{array}{c}-0.000 \\
(0.049)\end{array}$ & $\begin{array}{l}-0.043 \\
(0.036)\end{array}$ & $\begin{array}{c}-0.041 \\
(0.029)\end{array}$ & $\begin{array}{c}6.850 \\
(4.428)\end{array}$ & $\begin{array}{c}-0.141 \\
(0.107)\end{array}$ & $\begin{array}{c}0.027 \\
(0.070)\end{array}$ & $\begin{array}{l}0.065 * \\
(0.034)\end{array}$ & $\begin{array}{l}0.058 * \\
(0.031)\end{array}$ \\
\hline Inflation Volatility & $\begin{array}{c}0.079 * * * \\
(0.029)\end{array}$ & $\begin{array}{c}0.031^{* * *} \\
(0.007)\end{array}$ & $\begin{array}{c}0.002 \\
(0.006)\end{array}$ & $\begin{array}{l}-0.005 \\
(0.005)\end{array}$ & $\begin{array}{l}-0.008 \\
(0.040)\end{array}$ & $\begin{array}{l}-0.014 \\
(0.011)\end{array}$ & $\begin{array}{c}0.010 \\
(0.016)\end{array}$ & $\begin{array}{c}0.008 \\
(0.005)\end{array}$ & $\begin{array}{c}-0.014 \\
(0.010)\end{array}$ & $\begin{array}{l}-0.009 \\
(0.066)\end{array}$ \\
\hline No. of Movers & 18 & 28 & 35 & 36 & 37 & 5 & 7 & 12 & 6 & 11 \\
\hline Observations & 55 & 80 & 100 & 115 & 116 & 55 & 80 & 100 & 115 & 116 \\
\hline
\end{tabular}

Notes: In these probit regressions, the dependent variable for (1) to (5) pertains to a dummy variable which takes the value of 1 if a country has moved to a higher quintile income group regardless of which quintile income group it belonged in a given decade and regardless of which decade it has moved. The dependent variable for (6) to (10) pertains to a dummy variable which takes a value of 1 if a country has moved to a higher quintile income group in the following decade regardless of which quintile income group it belonged in the current decade; and 0 otherwise. Per capita income refers to log value of real GDP per capita. Interaction term is computed as the physical capital growth minus population growth plus human capital growth. Productivity growth refers to within decade growth rate. Civil liberties is an index. S-I Gap, or saving-investment gap, and oil share are in percent of GDP. Inflation volatility refers to within decade standard deviation of inflation. Robust standard errors are used. ${ }^{* \star},{ }^{* \star}$, and ${ }^{*}$ significant at $1 \%, 5 \%$ and $10 \%$, respectively.

Source: Authors' estimates. 
Table 8: Determinants of Moving to a Higher Income Group (using quality of human capital)

\begin{tabular}{l|cc|cc}
\hline \hline & $\mathbf{1 9 9 0 s}$ & $\mathbf{2 0 0 0 s}$ & $\mathbf{1 9 9 0 s}$ & $\mathbf{2 0 0 0 s}$ \\
VARIABLES & $(\mathbf{1})$ & $\mathbf{( 2 )}$ & $\mathbf{( 3 )}$ & $\mathbf{( 4 )}$ \\
\hline \multirow{4}{*}{ Per capita income } & & & & \\
& $-1.818^{* * *}$ & $-0.891^{*}$ & $-4.790^{* * *}$ & -1.551 \\
Population Growth & $(0.607)$ & $(0.529)$ & $(1.115)$ & $(1.100)$ \\
& 0.588 & -0.016 & 0.519 & 0.230 \\
Physical Capital Growth & $(1.150)$ & $(0.253)$ & $(1.113)$ & $(0.419)$ \\
& $1.169 * * *$ & -0.026 & 0.103 & 0.048 \\
Productivity Growth & $(0.414)$ & $(0.303)$ & $(0.731)$ & $(0.376)$ \\
& $0.076 * *$ & $-0.031^{* *}$ & $-0.165 * * *$ & -0.011 \\
Human Capital Quality & $(0.038)$ & $(0.015)$ & $(0.050)$ & $(0.019)$ \\
& $2.642 * * *$ & $1.839 * *$ & $3.263 * *$ & 1.738 \\
Civil Liberties & $(0.911)$ & $(0.809)$ & $(1.509)$ & $(1.511)$ \\
& -0.405 & $-0.541^{* * *}$ & $3.629 * * *$ & 0.196 \\
S-I Gap & $(0.415)$ & $(0.204)$ & $(1.171)$ & $(0.468)$ \\
& 0.019 & 0.009 & 0.084 & -0.042 \\
Oil Share & $(0.045)$ & $(0.024)$ & $(0.057)$ & $(0.041)$ \\
& -0.062 & -0.021 & $0.766 * * *$ & $0.119 *$ \\
Inflation Volatility & $(0.064)$ & $(0.027)$ & $(0.242)$ & $(0.062)$ \\
& -0.000 & -0.048 & -0.076 & -0.017 \\
No. of Movers & $(0.028)$ & $(0.063)$ & $(0.072)$ & $(0.114)$ \\
\hline \hline & & & & \\
& 16 & 21 & 2 & 7 \\
& 52 & 52 & 52 & 52 \\
\hline
\end{tabular}

Notes: In these probit regressions, the dependent variable for (1) to (2) pertains to a dummy variable which takes the value of 1 if a country has moved to a higher quintile income group regardless of which quintile income group it follows into in a given decade and regardless of which decade it has moved. The dependent variable for (3) to (4) pertains to a dummy variable which takes a value of 1 if a country has moved to a higher quintile income group in the following decade regardless of which quintile income group it belonged in the current decade; and 0 otherwise. Per capita income refers to log value of real GDP per capita. Population, physical capital, and productivity growth rates refer to within decade growth rates. Human capital quality refers to the log value of decade average math and science scores based on the National Center for Education Statistics (NCES) Trends in International Mathematics and Science Study (TIMSS) data. Civil liberties is an index. S-I Gap, or saving-investment gap, and oil share are in percent of GDP. Inflation volatility refers to within decade standard deviation of inflation. Robust standard errors are used. ${ }^{* *}{ }^{* *}{ }^{*}$, and ${ }^{*}$ significant at $1 \%, 5 \%$ and $10 \%$, respectively. Source: Authors' estimates. 
Table 9: Determinants of Moving to a Higher Income Group

(using quartile income grouping)

\begin{tabular}{|c|c|c|c|c|c|c|c|c|c|c|}
\hline \multirow[b]{2}{*}{ VARIABLES } & \multicolumn{2}{|c|}{ 1960s } & \multicolumn{2}{|c|}{$1970 \mathrm{~s}$} & \multicolumn{2}{|c|}{$1980 \mathrm{~s}$} & \multicolumn{2}{|c|}{$1990 \mathrm{~s}$} & \multicolumn{2}{|c|}{$2000 s$} \\
\hline & (1) & $(2)$ & $(3)$ & (4) & $(5)$ & $(6)$ & $(7)$ & $(8)$ & (9) & $(10)$ \\
\hline \multirow[t]{2}{*}{ Per capita income } & -0.544 & -0.590 & $-0.506 * * *$ & $-0.447^{*}$ & $-0.501 * * *$ & $-0.755^{* * *}$ & $-0.245^{*}$ & $-0.399 * *$ & $-0.729 * * *$ & $-0.619 *$ \\
\hline & $(0.525)$ & $(0.551)$ & $(0.135)$ & $(0.236)$ & $(0.156)$ & $(0.243)$ & $(0.137)$ & $(0.194)$ & $(0.236)$ & $(0.360)$ \\
\hline \multirow[t]{2}{*}{ Population Growth } & -0.447 & -0.434 & -0.358 & -0.890 & -0.261 & -1.477 & -0.120 & -0.133 & $-1.477 * * *$ & $-0.955 * * *$ \\
\hline & $(1.389)$ & $(1.435)$ & $(0.389)$ & $(0.735)$ & $(0.322)$ & $(1.686)$ & $(0.293)$ & $(0.754)$ & $(0.381)$ & $(0.325)$ \\
\hline \multirow[t]{2}{*}{ Physical Capital Growth } & $0.987 * *$ & $1.004 *$ & $0.482 * *$ & 0.548 & $0.661 * * *$ & 0.836 & 0.450 & $1.031^{* *}$ & $0.937 * * *$ & 0.604 \\
\hline & $(0.498)$ & $(0.528)$ & $(0.234)$ & $(0.391)$ & (0.199) & $(0.596)$ & $(0.342)$ & $(0.452)$ & $(0.329)$ & $(0.454)$ \\
\hline \multirow[t]{2}{*}{ Productivity Growth } & & $\ldots$ & & 0.033 & & -0.019 & & $\ldots$ & & 0.013 \\
\hline & & $\ldots$ & & $(0.024)$ & & $(0.024)$ & & $\ldots$ & & $(0.018)$ \\
\hline \multirow[t]{2}{*}{ Human Capital Growth } & & $0.071 *$ & & 0.045 & & $0.194 * *$ & & 0.009 & & 0.024 \\
\hline & & $(0.041)$ & & $(0.076)$ & & $(0.098)$ & & $(0.076)$ & & (0.091) \\
\hline \multirow[t]{2}{*}{ Civil Liberties } & 0.126 & 0.123 & 0.144 & -0.191 & 0.254 & $0.430 *$ & -0.265 & -0.352 & 0.509 & 0.369 \\
\hline & $(0.438)$ & $(0.444)$ & $(0.185)$ & $(0.292)$ & $(0.194)$ & $(0.234)$ & $(0.231)$ & $(0.354)$ & $(0.339)$ & $(0.521)$ \\
\hline \multirow[t]{2}{*}{ S-I Gap } & 0.010 & 0.015 & -0.029 & -0.064 & 0.000 & 0.008 & 0.036 & 0.045 & 0.042 & 0.047 \\
\hline & $(0.030)$ & $(0.031)$ & $(0.021)$ & $(0.052)$ & $(0.025)$ & $(0.041)$ & $(0.025)$ & $(0.042)$ & $(0.032)$ & $(0.056)$ \\
\hline \multirow[t]{2}{*}{ Oil Share } & -11.615 & -11.499 & 0.045 & 0.125 & 0.017 & -0.051 & $0.058^{* *}$ & $0.081^{* *}$ & $0.087^{* * *}$ & -0.042 \\
\hline & $(17.596)$ & (16.259) & $(0.053)$ & $(0.101)$ & $(0.050)$ & $(0.064)$ & $(0.027)$ & $(0.032)$ & $(0.032)$ & $(0.081)$ \\
\hline \multirow[t]{2}{*}{ Inflation Volatility } & -0.111 & $-0.142 *$ & $0.025^{*}$ & $0.036 * *$ & -0.014 & -0.019 & -0.008 & -0.019 & 0.003 & 0.046 \\
\hline & $(0.069)$ & $(0.078)$ & $(0.015)$ & $(0.015)$ & $(0.010)$ & (0.019) & $(0.006)$ & $(0.023)$ & $(0.040)$ & $(0.082)$ \\
\hline No. of Movers & 4 & 4 & 16 & 9 & 12 & 10 & 12 & 8 & 10 & 6 \\
\hline Observations & 81 & 80 & 141 & 80 & 148 & 100 & 172 & 144 & 174 & 116 \\
\hline
\end{tabular}

Notes: In these probit regressions, the dependent variable pertains to a dummy variable which takes a value of 1 if a country has moved to a higher quartile income group in the following decade regardless of which quartile income group it belongs in the current decade; and 0 otherwise. Per capita income refers to log value of real GDP per capita. Population, physical capital, productivity, human capital growth rates refer to within decade growth rates. Civil liberties is an index. S-I Gap, or saving-investment gap, and oil share are in percent of GDP. Inflation volatility refers to within decade standard deviation of inflation. ... $=$ regressors excluded due to discontinuous iterative log pseudo-likelihood process. Robust standard errors are used. ${ }^{* *}$, ${ }^{* *}$, and ${ }^{*}$ significant at $1 \%, 5 \%$ and $10 \%$, respectively.

Source: Authors' estimates. 
Table 10: Determinants of Moving to a Higher Income Group

(excluding economics which transition to lower quintile income groups)

\begin{tabular}{|c|c|c|c|c|c|c|c|c|c|c|}
\hline \multirow[b]{2}{*}{ VARIABLES } & \multicolumn{2}{|c|}{$1960 s$} & \multicolumn{2}{|c|}{$1970 s$} & \multicolumn{2}{|c|}{$1980 \mathrm{~s}$} & \multicolumn{2}{|c|}{$1990 s$} & \multicolumn{2}{|c|}{$2000 s$} \\
\hline & $(1)$ & $(2)$ & (3) & $(4)$ & $(5)$ & $(6)$ & (7) & $(8)$ & (9) & (10) \\
\hline Per capita income & $\begin{array}{c}-0.510 * * \\
(0.206)\end{array}$ & $\begin{array}{c}-0.786 * * \\
(0.355)\end{array}$ & $\begin{array}{c}-0.549 * * * \\
(0.164)\end{array}$ & $\begin{array}{c}-1.138 * * \\
(0.571)\end{array}$ & $\begin{array}{c}-0.840 * * * \\
(0.238)\end{array}$ & $\begin{array}{c}-0.600 * * * \\
(0.172)\end{array}$ & $\begin{array}{c}-0.905^{* * *} \\
(0.202)\end{array}$ & $\begin{array}{c}-1.687^{* * *} \\
(0.586)\end{array}$ & $\begin{array}{c}-0.336^{* *} \\
(0.150)\end{array}$ & $\begin{array}{c}-0.381^{*} \\
(0.195)\end{array}$ \\
\hline Population Growth & $\begin{array}{c}0.210 \\
(0.348)\end{array}$ & $\begin{array}{c}0.802 \\
(0.905)\end{array}$ & $\begin{array}{c}-0.182 \\
(0.361)\end{array}$ & $\begin{array}{c}0.379 \\
(0.697)\end{array}$ & $\begin{array}{c}-1.215^{* *} \\
(0.483)\end{array}$ & $\begin{array}{c}-2.314^{* * *} \\
(0.755)\end{array}$ & $\begin{array}{c}0.464 \\
(0.548)\end{array}$ & $\begin{array}{l}-1.690 \\
(1.360)\end{array}$ & $\begin{array}{c}-1.867 * * * \\
(0.534)\end{array}$ & $\begin{array}{c}-1.395^{* *} \\
(0.573)\end{array}$ \\
\hline Physical Capital Growth & $\begin{array}{c}0.743 \\
(0.499)\end{array}$ & $\begin{array}{c}0.555 \\
(0.353)\end{array}$ & $\begin{array}{c}0.732^{* * *} \\
(0.189)\end{array}$ & $\begin{array}{c}0.934 \\
(0.620)\end{array}$ & $\begin{array}{c}1.974^{* * *} \\
(0.578)\end{array}$ & $\begin{array}{c}1.202^{* * *} \\
(0.389)\end{array}$ & $\begin{array}{c}1.475^{* * *} \\
(0.400)\end{array}$ & $\begin{array}{c}2.281^{* * *} \\
(0.704)\end{array}$ & $\begin{array}{c}0.977^{* * *} \\
(0.266)\end{array}$ & $\begin{array}{c}0.926 * * * \\
(0.274)\end{array}$ \\
\hline Productivity Growth & & $\begin{array}{c}0.048 \\
(0.040)\end{array}$ & & $\begin{array}{c}0.033 \\
(0.030)\end{array}$ & & $\begin{array}{c}0.015 \\
(0.031)\end{array}$ & & $\begin{array}{l}\ldots \\
\ldots\end{array}$ & & $\begin{array}{c}0.011 \\
(0.011)\end{array}$ \\
\hline Human Capital Growth & & $\begin{array}{c}0.258 * * * \\
(0.096)\end{array}$ & & $\begin{array}{c}0.248 * * \\
(0.123)\end{array}$ & & $\begin{array}{c}0.072 \\
(0.048)\end{array}$ & & $\begin{array}{c}0.261^{* *} \\
(0.130)\end{array}$ & & $\begin{array}{c}0.012 \\
(0.072)\end{array}$ \\
\hline Civil Liberties & $\begin{array}{c}-0.256 * * * \\
(0.095)\end{array}$ & $\begin{array}{l}-0.539 \\
(0.350)\end{array}$ & $\begin{array}{c}0.205 \\
(0.219)\end{array}$ & $\begin{array}{c}0.233 \\
(0.449)\end{array}$ & $\begin{array}{c}0.172 \\
(0.325)\end{array}$ & $\begin{array}{c}0.088 \\
(0.364)\end{array}$ & $\begin{array}{c}0.030 \\
(0.367)\end{array}$ & $\begin{array}{c}0.650 \\
(0.579)\end{array}$ & $\begin{array}{c}-0.234 \\
(0.252)\end{array}$ & $\begin{array}{c}-0.236 \\
(0.293)\end{array}$ \\
\hline S-I Gap & $\begin{array}{c}0.016 \\
(0.042)\end{array}$ & $\begin{array}{c}0.025 \\
(0.207)\end{array}$ & $\begin{array}{c}0.032 \\
(0.036)\end{array}$ & $\begin{array}{c}0.166^{* *} \\
(0.072)\end{array}$ & $\begin{array}{c}0.039 \\
(0.036)\end{array}$ & $\begin{array}{c}0.004 \\
(0.064)\end{array}$ & $\begin{array}{c}-0.008 \\
(0.023)\end{array}$ & $\begin{array}{c}-0.133^{*} \\
(0.069)\end{array}$ & $\begin{array}{c}0.049 * * \\
(0.021)\end{array}$ & $\begin{array}{c}0.034 \\
(0.026)\end{array}$ \\
\hline Oil Share & $\begin{array}{c}-9.484 \\
(17.009)\end{array}$ & $\begin{array}{l}-2.473 \\
(9.170)\end{array}$ & $\begin{array}{c}-0.024 \\
(0.049)\end{array}$ & $\begin{array}{l}-0.157 \\
(0.183)\end{array}$ & $\begin{array}{c}0.053 \\
(0.066)\end{array}$ & $\begin{array}{c}0.103 \\
(0.099)\end{array}$ & $\begin{array}{c}0.065^{* *} \\
(0.030)\end{array}$ & $\begin{array}{c}0.092 \\
(0.057)\end{array}$ & $\begin{array}{c}0.061^{* * *} \\
(0.020)\end{array}$ & $\begin{array}{l}-0.001 \\
(0.038)\end{array}$ \\
\hline Inflation Volatility & $\begin{array}{c}0.010 \\
(0.015)\end{array}$ & $\begin{array}{l}-0.019 \\
(0.021)\end{array}$ & $\begin{array}{l}-0.022 \\
(0.042)\end{array}$ & $\begin{array}{c}0.022 \\
(0.025)\end{array}$ & $\begin{array}{c}0.023^{* * *} \\
(0.007)\end{array}$ & $\begin{array}{c}0.020 * * * \\
(0.006)\end{array}$ & $\begin{array}{l}-0.016 \\
(0.018)\end{array}$ & $\begin{array}{l}-0.011 \\
(0.021)\end{array}$ & $\begin{array}{c}0.038 \\
(0.034)\end{array}$ & $\begin{array}{c}0.104 \\
(0.074)\end{array}$ \\
\hline No. of Movers & 3 & 3 & 12 & 6 & 7 & 5 & 6 & 5 & 12 & 7 \\
\hline Observations & 81 & 55 & 141 & 80 & 148 & 100 & 172 & 144 & 174 & 116 \\
\hline
\end{tabular}

Notes: Movers exclude countries that transition to a lower quintile income group after having transitioned to a higher quintile income group in the previous decades In these probit regressions, the dependent variable pertains to a dummy variable which takes a value of 1 if a country has moved to a higher quintile income group in the following decade regardless of which quintile income group it belongs in the current decade; and 0 otherwise. Per capita income refers to log value of real GDP per capita. Population, physical capital, productivity, human capital growth rates refer to within decade growth rates. Civil liberties is an index. S-I Gap, or saving-investment gap, and oil share are in percent of GDP. Inflation volatility refers to within decade standard deviation of inflation. ... $=$ regressors excluded due to discontinuous iterative log pseudo-likelihood process. Robust standard errors are used. *** ${ }^{* *}$, and * significant at $1 \%, 5 \%$ and $10 \%$, respectively. Source: Authors' estimates. 